\title{
Characterization of aerosol sources in León (Spain) using Positive Matrix Factorization and weather types
}

\author{
Fernanda Oduber ${ }^{\mathrm{a}}$, Ana Isabel Calvo ${ }^{\mathrm{a}, *}$, Amaya Castro $^{\mathrm{a}}$, Carlos Blanco-Alegre ${ }^{\mathrm{a}}$, Célia Alves ${ }^{\mathrm{b}}$, Giulia Calzolai $^{\mathrm{c}}$, \\ Silvia Nava ${ }^{\mathrm{c}}$, Franco Lucarelli ${ }^{\mathrm{c}}$, Teresa Nunes ${ }^{\mathrm{b}}$, Joana Barata ${ }^{\mathrm{b}}$, Roberto Fraile $^{\mathrm{a}}$ \\ a Department of Physics, IMARENAB University of León, León, Spain \\ b Centre for Environmental and Marine Studies, Department of Environment, University of Aveiro, Aveiro, Portugal \\ ${ }^{c}$ Department of Physics and Astronomy, University of Florence and INFN-Florence, Florence, Italy
}

\section{H I G H L I G H T S}

- A one-year aerosol sampling period was conducted in León (Spain) to label the sources.

- The PMF found 6 main aerosol contributors, from traffic (29\%) to biomass burning (3\%).

- A linear model estimates each source supply to $\mathrm{PM}_{10}$ from tracer elements and airflows.

- PMF analysis along with circulation weather types provide a good estimation for $\mathrm{PM}_{10}$.

- MLR models built offer a simplification for determining source apportionment.

\section{A R T I C L E I N F O}

\section{Article history:}

Received 2 May 2020

Received in revised form 24 August 2020

Accepted 26 August 2020

Available online 27 August 2020

Editor: Pavlos Kassomenos

\section{Keywords:}

Aerosol

Circulation weather types

Linear models

PMF

Source apportionment

\section{G R A P H I C A L A B S T R A C T}

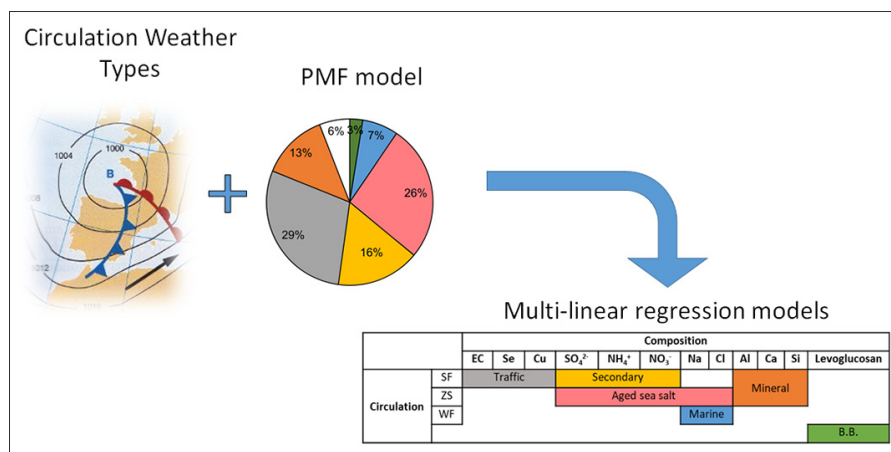

\begin{abstract}
A B S T R A C T
A one-year aerosol sampling campaign, between 2016 and 2017, was conducted in a suburban area of León city, Spain. An association between the Positive Matrix Factorization (PMF) results and air masses through circulation weather types was carried out, through the construction of linear models from the $\mathrm{PM}_{10}$ concentrations and its chemical composition. The aerosol sources, identified by PMF six-factor solution, were: traffic (29\%), aged sea salt (26\%), secondary aerosols (16\%), dust (13\%), marine aerosol (7\%) and biomass burning (3\%). Traffic and secondary factors showed the highest $\mathrm{PM}_{10}$ contribution in the hybrid cyclonic types with wind component from the first and second quadrant. Anticyclonic types with wind component from the first quadrant exhibited high values of secondary, aged sea salt and dust factors. The highest contributions of the dust factor were also associated with northerly types. The linear models built for estimating the source apportionment of $\mathrm{PM}_{10}$, from aerosol chemical composition and geostrophic flow, showed positive coefficients for: westerly flows (WF) in marine factor, southerly flows (SF) in secondary and traffic factors, and shear southerly vorticities (ZS) in dust factor. Negative dependences were observed for ZS in aged sea salt factor and for SF in dust factor. The $\mathrm{PM}_{10}$ mass concentration calculated by the linear models and by the PMF model were strongly correlated. This can be very useful to determine the contribution of a specific source to $\mathrm{PM}_{10}$ in León, only by knowing some meteorological and chemical variables.
\end{abstract}

(C) 2020 Elsevier B.V. All rights reserved.

\footnotetext{
* Corresponding author.

E-mail addresses: fodup@unileon.es (F. Oduber), aicalg@unileon.es (A.I. Calvo), acasi@unileon.es (A. Castro), cblaa@unileon.es (C. Blanco-Alegre), celia.alves@ua.pt (C. Alves), calzolai@fi.infn.it (G. Calzolai), nava@fi.infn.it (S. Nava), lucarelli@fi.infn.it (F. Lucarelli), tnunes@ua.pt (T. Nunes), jbarata@ua.pt (J. Barata), roberto.fraile@unileon.es (R. Fraile).
} 


\section{Introduction}

Aerosols are important components of the atmosphere and are defined as particles in solid or liquid state which are suspended in the air (Mészáros, 1999). Physical, chemical and optical characteristics of atmospheric aerosols depend largely on their sources and formation processes. Depending of these characteristics, atmospheric aerosols impact the local and regional air quality (Paraskevopoulou et al., 2015), visibility reduction and health (Kanakidou et al., 2005; Ren-Jian et al., 2012). Atmospheric aerosol sources can be divided into: i) natural, which include seas, volcanoes, vegetation, wildfires, deserts and soil resuspension and ii) anthropogenic, which are caused by human activities, mainly in urban and industrial areas, such as exhaust and other traffic related emissions, industrial activities, fossil fuel combustion, cooking, and biomass burning (Calvo et al., 2013).

At a specific location, aerosol concentrations depend on several factors such as meteorological conditions, regional background, local and regional sources. Thus, the study of the distribution of sources allows the reconstruction of the patterns of pollution sources, with the objective of devising mitigation strategies to improve air quality.

The role of meteorological conditions in the atmospheric processes of dilution, transformation, transport and removal of pollutants has been widely studied in recent years (e.g. Baltaci et al., 2019; Gvozdić et al., 2011; Kuzu and Saral, 2017). The concentration of pollutants in the atmosphere is also linked to the occurrence of specific weather features (including wind speed and direction) induced by mesoscale processes (e.g. Baltaci et al., 2019; Calvo et al., 2012; Kwok et al., 2017; Russo et al., 2014; Weissert et al., 2018), which are specific to a given region. Thus, the weather types and the origin of air masses provide valuable information on the influence of polluting sources at a given study area (Calvo et al., 2012).

Different source apportionment models are available to identify ambient air pollution sources and quantify their contribution to measured levels. Viana et al. (2008) described three main groups of source apportionment techniques: i) methods based on the evaluation of monitoring data (including correlations between wind direction and particulate matter (PM) components); ii) methods based on emission inventories and/or dispersion models; iii) receptor models to quantify the contribution of sources to PM from its chemical composition (Paatero and Tapper, 1994), which include models such as principal component analysis (PCA), positive matrix factorization (PMF), regression models, chemical mass balance (CMB), among others. Receptor models are widely used due to the availability of software that allows the identification of the sources. PMF is one of the most used and useful models, especially where detailed data do not exist on the composition of the main emission sources, but large datasets of ambient concentration are readily available (Lanz et al., 2007; Norris et al., 2014; Paatero and Tapper, 1994).

Throughout the years, authors have studied and identified the contribution of aerosol sources in different environments (e.g. Amato et al., 2016; Cesari et al., 2016; Mazzei et al., 2008; Paraskevopoulou et al., 2015). In Spain, several aerosol source apportionment have been carried out using PMF (Aldabe et al., 2011; Cusack et al., 2013; Pindado and Perez, 2011; Titos et al., 2014; Yubero et al., 2011) or other techniques (Artiñano et al., 2003; Pey et al., 2009; Querol et al., 2001, 2002), especially in large urban centers such as Barcelona and Madrid, where the main primary sources are involved (e.g. traffic or fossil fuel combustion) or at rural sites highly impacted by biomass burning.

Previous studies carried out in León city (NW of Spain), described it as a city mainly affected by fossil fuel and biomass burning emissions, due to road traffic and domestic heating devices (Blanco-Alegre et al., 2019; Oduber et al., 2018) specially in autumn and winter. Moreover, the northwest of the Iberian Peninsula is often affected by long-range transport events, such as Saharan dust intrusions and wildfires, which can cause an increase in the particulate concentrations and changes in the aerosol chemical composition (Alonso-Blanco et al., 2012, 2018; Oduber et al., 2019). However, until now no previous studies described in depth the aerosol chemical composition and their possible sources in León city.

As discussed above, both meteorological characteristics (regional state of the atmosphere) and source apportionment methods are useful tools in air quality studies. However, studies combining these approaches and taking advantage of potential synergies between them are scarce. This study aims to fill this gap with the analysis of the link between the source contributions and the circulation weather types in a suburban area of León city, Spain. For this purpose, attempts were made to establish multi-linear regression models (MLR) integrating the daily contribution of each source to $\mathrm{PM}_{10}$ and the parameters of weather types associated with the geostrophic flow: southerly flow (SF), westerly flow (WF), southerly shear vorticity (ZS) and westerly shear vorticity $(\mathrm{ZW})$. Besides, the main influence of the sources during the different circulation weather types and the relationship with the meteorological conditions, were also analyzed. As far as we know, this is the first time such an approach is taken in studies of aerosol source apportionment, which will represent a step forward in this kind of studies.

\section{Experimental background}

\subsection{Sampling site}

Atmospheric aerosols were sampled between 09 March 2016 and 14 March 2017, on the terrace of the Faculty of Veterinary Sciences at the University of León ( $42^{\circ} 36^{\prime} 50^{\prime \prime} \mathrm{N}, 5^{\circ} 33^{\prime} 38^{\prime \prime} \mathrm{W}, 846 \mathrm{~m}$ ), about $12 \mathrm{~m}$ above ground level, in a suburban area located in the NE of the urban center of León city, Spain (Fig. 1). The city is characterized by the absence of large emitting industries, except for some pharmaceutical industries located around the city within a radius of $5 \mathrm{~km}$. In La Robla, $30 \mathrm{~km}$ north of the city, there is also a cement factory (Fig. 1). The National Institute for Statistics (www.ine.es) reported that the city of León had a population of 125,317 inhabitants in 2017.

The climate in León is Continental type with great influence of the Mediterranean climate, with long and cold winters and warm summers (Table 1). The mean annual temperature is $11^{\circ} \mathrm{C}$, influenced by the proximity of the Cantabrian Mountain Range to the north. Minimum precipitation values are recorded in summer, when droughts are very common, while spring is the season with maximum precipitation values (Table 1). In winter there are frequent frosts ( 74 frost days per year, on average) and, on average, 16 snow days are registered per year, but large snowfalls are not frequent (Castro et al., 2010).

\subsection{Materials and methods}

\subsubsection{Aerosol sampling and chemical analysis}

The sampling of $\mathrm{PM}_{10}$ was carried out using a low volume sampler (TECORA, ECHOPM) equipped with $47 \mathrm{~mm}$ diameter teflon filters and a high-volume sampler (CAV-Mb) equipped with $150 \mathrm{~mm}$ diameter quartz filters. The filter samples were collected every $24 \mathrm{~h}$, starting at 1200 UTC every day.

2.2.1.1. Quartz filters. Quartz filters were used for the determination of $\mathrm{PM}_{10}$ mass by gravimetry, weighing the filters before and after sampling $( \pm 0.00001 \mathrm{~g})$ on an electronic semi-microbalance (Mettler Toledo, XPE105DR).

The determination of organic and elemental carbon (OC and EC, respectively) was carried out using the thermal-optical technique, following the procedure described in Alves et al. (2015) and Pio et al. (2011). To account for elements such as oxygen, hydrogen and nitrogen, the amount of particulate organic matter (POM) has been estimated by multiplying the average OC concentration by a factor of 1.6 (Liousse et al., 1996). 

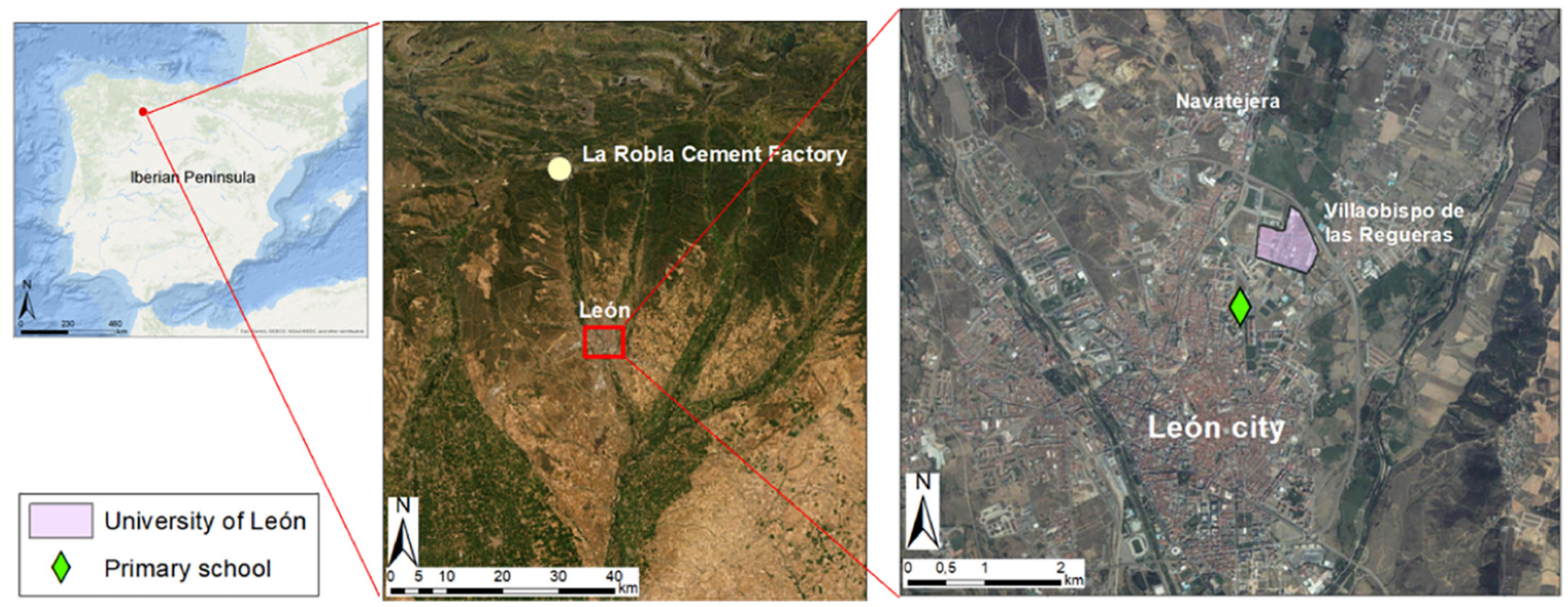

Fig. 1. Map of the Iberian Peninsula and location of the sampling site.

A portion of the quartz filters was extracted with $3 \mathrm{ml}$ of ultra-pure deionized water and filtered through a $0.2 \mu \mathrm{m}$ PTFE syringe filter for the determination of levoglucosan, which is used as a tracer of biomass burning emissions (Simoneit et al., 1999; Vicente and Alves, 2018). The extracts were analyzed in a Thermo Scientific Dionex ${ }^{\mathrm{TM}}$ ICS-5000 ion chromatograph equipped with amperometric detector and a CarboPac $®$ PA- 1 column $(2 \times 250 \mathrm{~mm})$, and quantified through a calibration curve made from a levoglucosan standard (Sigma-Aldrich, 99\% purity).

2.2.1.2. Teflon filters. Teflon filters were first cut in half. One half was used for the analysis of water-soluble inorganic ions by ion chromatography (IC). This portion was extracted with $6 \mathrm{ml}$ of ultra-pure deionized water and filtered through a $0.2 \mu \mathrm{m}$ PTFE syringe filter. The chromatographic analysis was performed on a Thermo Scientific Dionex ${ }^{\mathrm{TM}}$ ICS-5000 equipment provided with an IonPac ${ }^{\circledR}$ CS16 column $(4 \times 250 \mathrm{~mm})$ and an IonPac ${ }^{\circledR}$ AS11 column $(4 \times 250 \mathrm{~mm})$ for the analysis of cations $\left(\mathrm{Li}^{+}, \mathrm{Na}^{+}, \mathrm{K}^{+}, \mathrm{Ca}^{2+}, \mathrm{Mg}^{2+}, \mathrm{NH}_{4}^{+}\right)$and anions $\left(\mathrm{F}^{-}, \mathrm{Cl}^{-}, \mathrm{SO}_{4}^{2-}, \mathrm{NO}_{3}^{-}\right.$, $\mathrm{NO}_{2}^{-}$), respectively. The other half was used for the determination of the major trace elements ( $\mathrm{Na}, \mathrm{Mg}$, Al, Si, P, S, Cl, K, Ca, Ti, V, Cr, Mn, Fe, $\mathrm{Ni}, \mathrm{Cu}, \mathrm{Zn}, \mathrm{As}, \mathrm{Se}, \mathrm{Br}, \mathrm{Rb}, \mathrm{Sr}, \mathrm{Pb})$, using the Particle-Induced X-ray Emission (PIXE) technique described by Lucarelli et al. (2015).

\subsubsection{Circulation weather types}

A circulation weather type (CWT) classification, based on Lamb (1972), was carried out. The direction and vorticity of the geostrophic flow (southerly flow SF, westerly flow WF, southerly shear vorticity ZS and westerly shear vorticity ZW) were obtained from the atmospheric pressure at sea level in 16 grid points distributed over the Iberian Peninsula (Trigo and DaCamara, 2000). The data used in this study can be accessed at the National Center for Atmospheric Research (https:// ncar.ucar.edu, last accessed: 2 March 2020). The units of both the components of geostrophic flow (variables ending with $\mathrm{F}$ ) and of vorticity (variables beginning with $\mathrm{Z}$ ) are expressed as hPa per $10^{\circ}$ latitude at

Table 1

Annual and seasonal mean temperatures $(\mathrm{T})$, relative humidity (RH), accumulated precipitation (Prec.) and wind speed (ws) in León during the study period. Data were recorded by an automatic weather station located in the sampling site.

\begin{tabular}{lccccc}
\hline & Annual & Winter & Spring & Summer & Autumn \\
\hline $\mathrm{T}\left({ }^{\circ} \mathrm{C}\right)$ & $11 \pm 7$ & $5 \pm 3$ & $10 \pm 4$ & $20 \pm 4$ & $10 \pm 4$ \\
$\mathrm{RH}(\%)$ & $63 \pm 14$ & $70 \pm 12$ & $64 \pm 11$ & $48 \pm 7$ & $70 \pm 11$ \\
Prec. $(\mathrm{mm})$ & $485 \pm 3$ & $150 \pm 1$ & $229 \pm 1$ & $31.0 \pm 0.2$ & $75 \pm 1$ \\
ws $\left(\mathrm{m} \mathrm{s}^{-1}\right)$ & $0.8 \pm 0.7$ & $0.8 \pm 0.7$ & $1.2 \pm 0.8$ & $0.6 \pm 0.3$ & $0.7 \pm 0.5$ \\
\hline
\end{tabular}

$40^{\circ} \mathrm{N}$. These parameters have been used to establish each one of the 26 different CWTs: i) 8 "pure" weather types, (N, S, E, W, NW, SW, SE and NE); ii) 2 "non-directional" (anticyclonic-A and cyclonic-C); iii) 16 "hybrid" types, as a result of the combination between "non-directional" and "pure" types: AN, ANE, ANW, AS, ASE, ASW, AE, AW and CN, CNE, CNW, CS, CSE, CSW, CE, CW (Table S1). More information about this classification can be found in Fernández-Raga et al. (2017) and Trigo and DaCamara (2000).

\subsubsection{PMF model}

The analysis of the aerosols source contribution is carried out using receptor models like Positive Matrix Factorization (PMF). PMF is a multivariate factor analysis tool, developed by the U.S. Environmental Protection Agency (EPA), that decomposes a matrix of each sample data into two matrices: factor contributions $(G)$ and factor profiles $(F)$. The aim of this model is to solve the chemical mass balance (CMB) between the concentrations of each measured specie and the source profiles (Eq. (1)), using the number of factor $p$, the species profile $f$, the mass $g$ contributed by each factor to each sample. Thus,

$x_{i j}=\sum_{k=1}^{p} g_{i k} f_{k j}+e_{i j}$

where $x_{i j}$ is the concentration of chemical species $j$ measured with uncertainties $u, i$ is the number of samples, $f_{k j}$ is the concentration of species $j$ in factor profile $k, g_{i k}$ is the relative contribution of factor $k$ to sample $i$ and $e$ is the residue of each sample/species.

Factor profiles obtained have to be interpreted by the users to identify the source types, using source profile information (Paatero, 1997; Paatero et al., 2014; Paatero and Tapper, 1994). To the weight of each individual point, PMF use both sample concentration and user-provided uncertainty associated with the sample, and the factor contribution and profile are obtained minimizing the function $Q$ (Eq. (2))

$Q=\int_{i=1}^{n} \int_{j=1}^{m}\left[\frac{x_{i j}-\int_{k=1}^{p} g_{i k} f_{k j}}{u_{i j}}\right]^{2}$

where $n$ is the number of samples and $m$ is the number of species.

The model shows two values of $Q$ : $Q$ (true) and $Q$ (robust). The difference between those two parameters allow to measure the impact of data points with high scaled residuals. $Q$ (true) is the goodness-of-fit parameter that is calculated including all points and $Q$ (robust) is calculated excluding points that are not fit by the model. $Q$ (robust) is used for choose the optimal run from the multiple runs, due to this parameter 
is not influenced by points that are not fit by PMF, thus, the best solution is that which provide the lowest $Q$ (robust).

To run PMF, concentrations and uncertainties of the chemical properties of $364 \mathrm{PM}_{10}$ samples were used. Missing data were substituted by the median value and their uncertainties were replaced by four times the median value. The values below detection limits (BDL) were replaced by half of the minimum value reported and their uncertainties were replaced by $5 / 6$ times the detection limit value, according to the methodology used by Polissar et al. (1998).

\subsubsection{Additional data and data analysis}

Seasons have been defined as follows: i) winter: from 21 December to 20 March; ii) spring: from 21 March to 20 June; iii) summer: from 21 June to 20 September; and iv) autumn: from 21 September to 20 December. Temperature, wind speed and direction, relative humidity and precipitation data, were recorded by an automatic weather station located in the sampling site.

For the statistical treatment, SPSS software (IBM Statistics Software V. 24) and R software with the Openair package (Carslaw, 2015; Carslaw and Ropkins, 2012) were used. The Kruskal-Wallis nonparametric test (Kruskal and Wallis, 1952) followed by Dunn test (Dunn, 1964) were applied to obtain the statistically significant differences. An automatic linear modelling (IBM SPSS Statistics 24) by stepwise with a significance of 0.05 and a removal probability of 0.1 was also used (Agostinelli, 2002; Grego, 1993; Hastie et al., 2009; Kabe, 1963).

\section{Results and discussions}

\section{1. $P M_{10}$ mass concentrations and chemical composition}

During the sampling period, the mean annual $\mathrm{PM}_{10}$ mass concentration was $23 \pm 8 \mu \mathrm{g} \mathrm{m}^{-3}$. This value is similar to those reported in other suburban stations, during one-year sampling campaigns, by Waked et al. (2014) in Lens, France $\left(22 \pm 13 \mu \mathrm{g} \mathrm{m}^{-3}\right)$ and by Amato et al. (2016) in Barcelona, Spain $\left(22.5 \mu \mathrm{g} \mathrm{m}^{-3}\right)$ and in Athens, Greece $\left(19.8 \mu \mathrm{g} \mathrm{m}^{-3}\right)$. The minimum value of $4 \mu \mathrm{g} \mathrm{m}^{-3}$ was recorded between 12 and 13 March 2017, after a precipitation event. The maximum concentration $\left(59 \mu \mathrm{g} \mathrm{m}^{-3}\right.$ ) was reached between 23 and 24 February 2017, during an intense Saharan dust intrusion (Oduber et al., 2019). It was the only day in which the air quality daily limit value (DLV) for $\mathrm{PM}_{10}\left(50 \mu \mathrm{g} \mathrm{m}^{-3}\right.$, Directive $\left.2008 / 50 / \mathrm{CE}\right)$ was exceeded. The lowest mean seasonal $\mathrm{PM}_{10}$ value was registered in spring with $20 \pm$ $6 \mu \mathrm{g} \mathrm{m}^{-3}$ (Table S2). This season is characterized by low mean temperatures and high relative humidity (Table 1 ) and is usually very rainy, which helps to scavenge the aerosol.

Carbonaceous constituents (POM + EC), represented the highest $\mathrm{PM}_{10}$ mass fraction in all seasons, with an annual mean percentage of $19 \pm 6 \%$. Winter showed the highest carbonaceous fraction with $21 \pm 7 \%$ of $\mathrm{PM}_{10}$, and presented statistical significant differences compared to summer and autumn $(p<0.05)$. Calvo et al. (2013) describe that the primary anthropogenic OC and EC are mainly emitted by combustion processes, such as those involving road traffic and domestic heating devices. Levoglucosan (a tracer of biomass burning) concentrations were higher in winter and autumn than in summer, showing statistically significant differences between seasons $(p<0.01)$, indicating that, in summer, OC values are more closely related to bioaerosol sources and forest fires, while in winter and autumn biomass burning is a major contributor to this carbonaceous component.

The concentration of the elements related to the mineral fraction ( $\mathrm{Si}$, $\mathrm{Fe}, \mathrm{Ca}, \mathrm{Al}$ ) was higher in summer than in the other seasons (Table S2), due to the Saharan dust intrusions that reach the Peninsula during the warm months (Díaz et al., 2017). A significant correlation between $\mathrm{NH}_{4}^{+}$and both $\mathrm{SO}_{4}^{2-}$ and $\mathrm{NO}_{3}^{-}(r=0.69$ and 0.80 , respectively, $p<0.01$ ) was observed, suggesting that ammonium acts as neutralizer of sulfate and nitrate aerosols. The highest values of sulfate were observed in summer and spring, mainly due to the increase in the $\mathrm{SO}_{2}$ oxidation rate under high insolation conditions (Galindo et al., 2008; Seinfeld and Pandis, 2016). Moreover, the highest concentrations of nitrate were recorded in winter $\left(1.3 \pm 1.5 \mu \mathrm{g} \mathrm{m}^{-3}\right)$ (Table S2), due to the thermal stability of ammonium nitrate (Querol et al., 2004). Additionally, nitrate concentrations are affected by the $\mathrm{NO}_{\mathrm{x}}$ emissions from residential combustion devices (Vicente et al., 2013), and from exhaust systems of motor vehicles (Alves et al., 2015).

\subsection{PMF source apportionment}

Aerosol source apportionment was carried out by PMF analysis. The number of contributing factors was identified by modelling. The final number of factors was chosen according to a critical evaluation of the mathematical parameters of the solution and the physical reasonability of the factor profiles. With 5 factors the biomass burning factor could not be isolated. With 7 factors, chemical profiles were not well defined (for example, biomass burning and traffic factors did not include EC). The best adjustment was provided by a 6 -factor solution. The patterns obtained allowed to identify the following sources in the city of León (Fig. 2): traffic, aged sea salt, secondary aerosol, dust, marine, and biomass burning (B.B.). In addition, approximately $6 \%$ of the $\mathrm{PM}_{10}$ mass cannot be explained by any of the factors and was mentioned as an unknown fraction (Fig. 3).

Upon careful assessment of the uncertainties associated with the analytical techniques used (e.g. PIXE, IC), according to the Polissar approach (Polissar et al., 1998), every solution was thoroughly evaluated. For the final proposal of each model, most of the scaled residuals were between \pm 3.0 , with a random distribution of positive and negative values, and the reconstruction of the measured species was good (the difference was around 12\%).

\subsubsection{Traffic source}

Traffic, which includes exhaust and non-exhaust emissions, was the prevailing aerosol source in León city during the entire year, representing 29\% of $\mathrm{PM}_{10}$ (Fig. 3). Alleman et al. (2010) and Amato et al. (2016) also reported road transport as the main aerosol source in urban stations in France ( $15 \%$ of $\left.\mathrm{PM}_{10}\right)$ and Portugal $\left(23 \%\right.$ of $\left.\mathrm{PM}_{10}\right)$, respectively, while in background stations, the traffic contribution to $\mathrm{PM}_{10}$ ranged between 18 and 22\% in the study of Amato et al. (2016) (Table 2). This factor is characterized by high contributions of EC, OC, $\mathrm{NO}_{3}^{-}$and Se, which can be associated with fossil fuel emissions (Lin et al., 2005). Between autumn and winter a significant increase in the contribution of this aerosol source was observed, probably due to the academic activities of the study site. Additionally, not far from the sampling site there is the car park of the University of León ( $\sim 50 \mathrm{~m}$ east), a bus stop ( $\sim 150 \mathrm{~m}$ south) and a ring road ( $250 \mathrm{~m}$ northeast). Furthermore, the city center is located at about $2000 \mathrm{~m}$ south of the sampling point. A previous study carried out in León (Oduber et al., 2018) shows a significant decrease in the traffic emissions during summer due to the considerable reduction of traffic flow caused by the vacation period of the University of León and the primary school not far from the sampling point (Fig. 1). Planetary boundary layer height (PBL) is also a crucial parameter in the vertical mixing and dilution of pollutants close to the surface. In winter and autumn, PBL is lower, preventing the dilution of pollutants and promoting higher concentrations. Furthermore, the action of local meteorological parameters can obviously influence the concentrations (not only from traffic, but also for the rest of local sources).

\subsubsection{Aged sea salt source}

Aged sea salt was the second most important factor contributing to the annual $\mathrm{PM}_{10}$ with $26 \%$. Moreover, summer and spring are the seasons with the highest contribution (Fig. 3). Waked et al. (2014) reported a contribution of $19 \%$ of $\mathrm{PM}_{10}$ from aged sea salt aerosol in Lens, France, while Amato et al. (2016) reported contribution of $11 \%$ in Barcelona, 

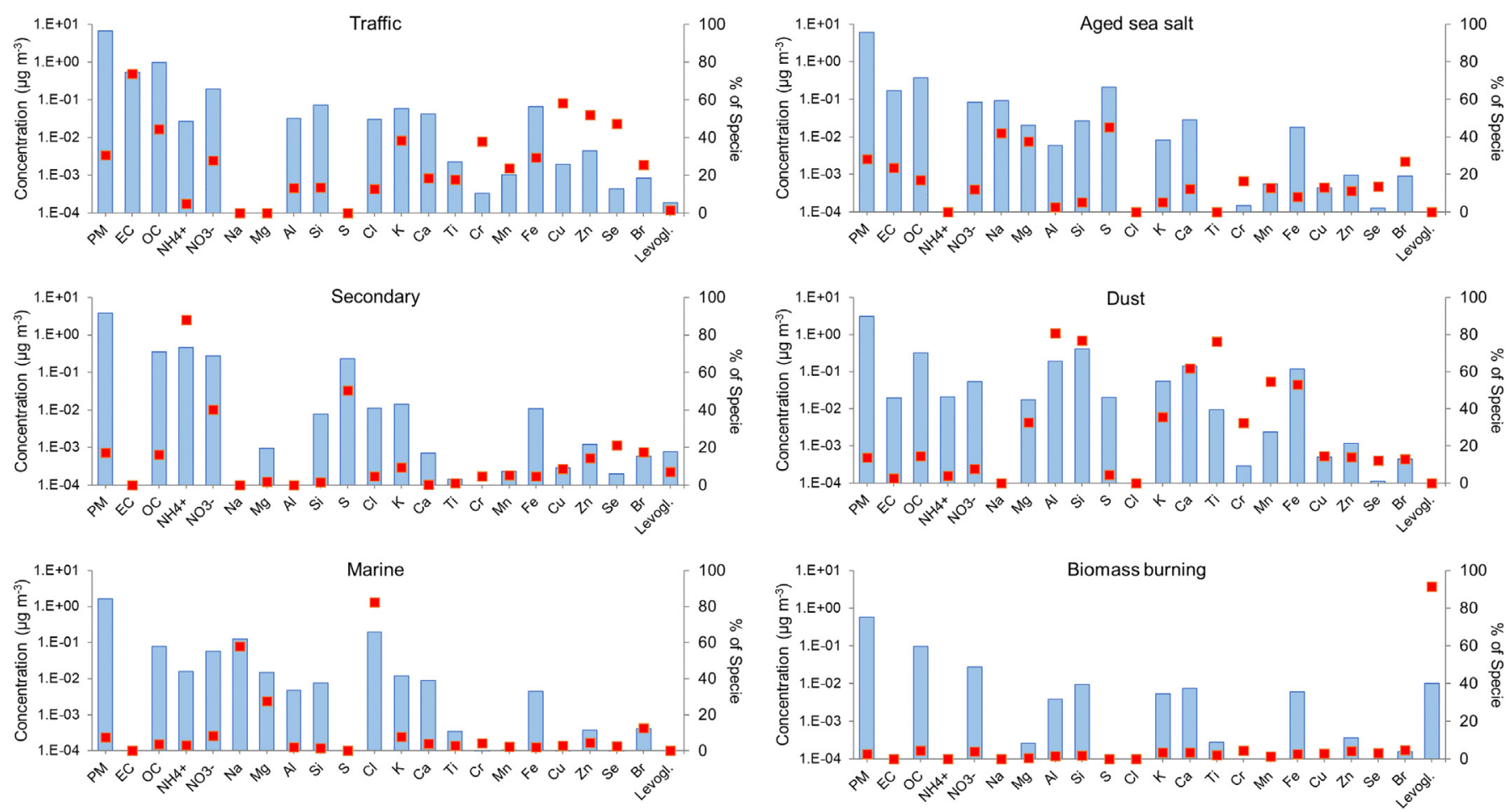

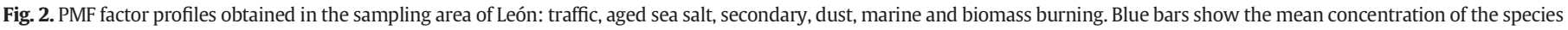

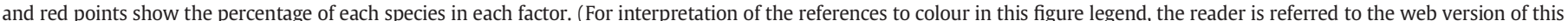
article.)

Spain, 5\% in Florence and 2\% in Milan, Italy (Table 2), coinciding in all cases with an increase in the contribution during summer.

Despite the fact that León is located relatively far from the coast, the chemical elements included in this factor indicate the presence of an aged marine aerosol, which has been transported by air masses. Furthermore, as the main transport pathways affect the air masses composition, high levels of crustal elements are probably incorporated to moving air during its trajectory to León. In fact, this factor is also
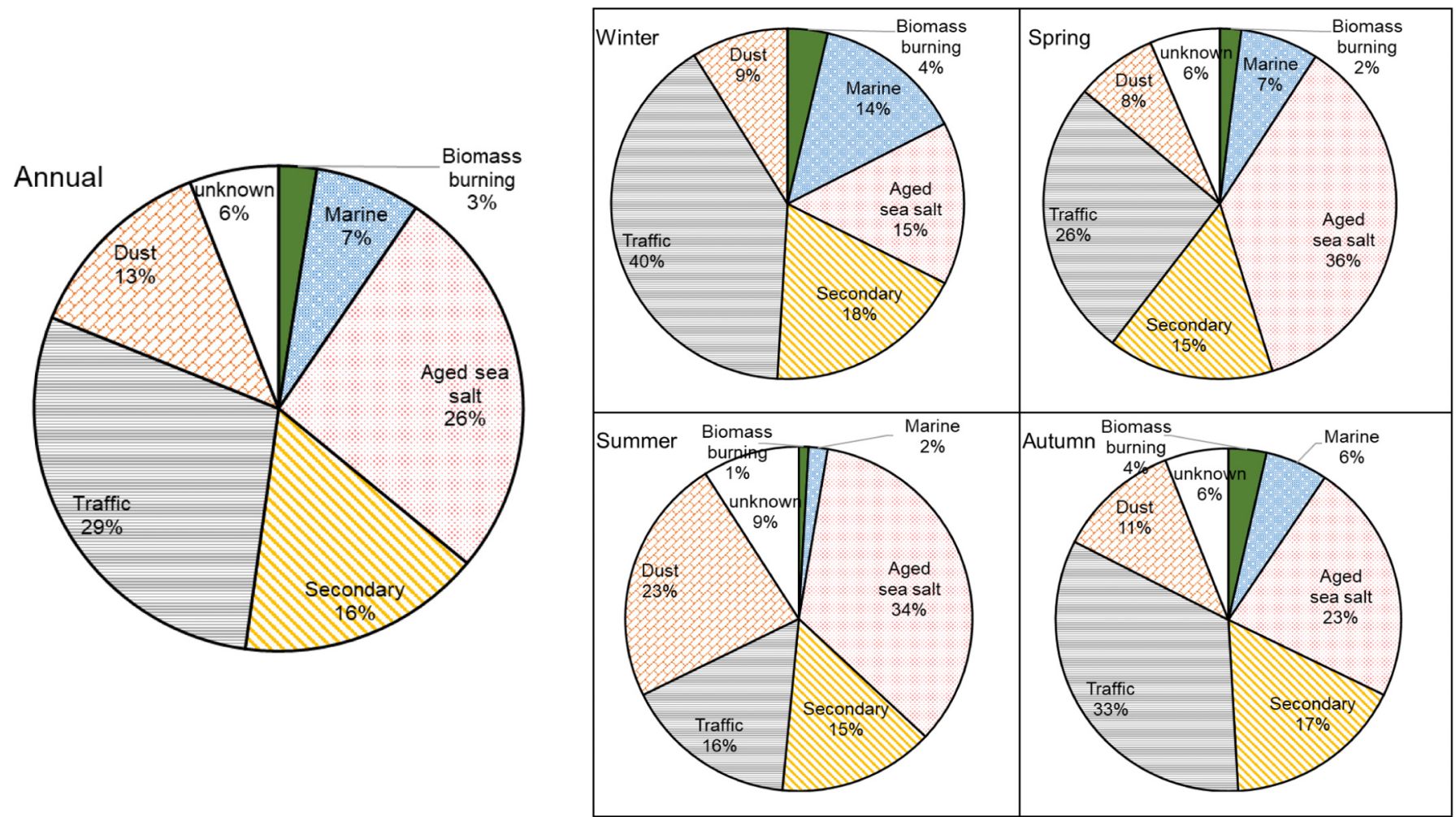

Fig. 3. Annual and seasonal contributions, in $\%$ of $\mathrm{PM}_{10}$, of the aerosol sources. 
Table 2

Source contributions of $\mathrm{PM}_{10}$ obtained with PMF by different studies.

\begin{tabular}{|c|c|c|c|}
\hline Study & Location & $\begin{array}{c}\mathrm{PM}_{10} \\
\left(\mu \mathrm{g} \mathrm{m} \mathrm{m}^{-3}\right)\end{array}$ & Sources (contribution to $\mathrm{PM}_{10}$ ) \\
\hline \multirow[t]{5}{*}{$\begin{array}{l}\text { Amato et al. } \\
\qquad(2016)\end{array}$} & $\begin{array}{l}\text { Barcelona, Spain } \\
\text { (urban background) }\end{array}$ & 23 & $\begin{array}{l}\text { Secondary sulfate and organics (27\%), secondary nitrate (13\%), vehicle exhaust (14\%), vehicle non-exhaust } \\
(12 \%) \text {, aged sea salt (11\%), local dust (11\%), industrial (7\%), heavy oil combustion (4\%), Saharan dust (1\%) }\end{array}$ \\
\hline & Porto, Portugal (urban traffic) & 34 & $\begin{array}{l}\text { Vehicle exhaust ( } 23 \%) \text {, mineral (18\%), fresh sea salt (16\%), biomass burning (12\%), heavy oil and secondary } \\
\text { sulfate (10\%), secondary nitrate ( } 9 \%) \text {, vehicle non-exhaust }(8 \%) \text {, industrial }(4 \%)\end{array}$ \\
\hline & $\begin{array}{l}\text { Florence, Italy (urban } \\
\text { background) }\end{array}$ & 19 & $\begin{array}{c}\text { Secondary sulfate and organics ( } 21 \%) \text {, biomass burning ( } 15 \%) \text {, vehicle exhaust ( } 13 \%) \text {, local dust (12\%), } \\
\text { secondary nitrate ( } 11 \%) \text {, vehicle non-exhaust }(9 \%) \text {, heavy oil combustion }(5 \%) \text {, aged sea salt ( } 5 \%) \text {, Saharan } \\
\text { dust }(4 \%) \text {, fresh sea salt }(4 \%)\end{array}$ \\
\hline & $\begin{array}{l}\text { Milan, Italy (urban } \\
\text { background) }\end{array}$ & 38 & $\begin{array}{l}\text { Secondary nitrate (26\%), biomass burning (17\%), vehicle non-exhaust (14\%), secondary sulfate and organics } \\
\qquad(13 \%) \text {, local dust (8\%), industrial ( } 8 \%) \text {, vehicle exhaust }(7 \%) \text {, aged sea salt }(2 \%)\end{array}$ \\
\hline & $\begin{array}{l}\text { Athens, Greece } \\
\text { (suburban background) }\end{array}$ & 20 & $\begin{array}{c}\text { Secondary sulfate and organics (19\%), secondary nitrate (15\%), Saharan dust (14\%), local dust (11\%), vehicle } \\
\text { exhaust (10\%), vehicle non-exhaust ( } 8 \%) \text {, biomass burning (7\%), fresh sea salt (5\%), heavy oil combustion } \\
(4 \%)\end{array}$ \\
\hline $\begin{array}{l}\text { Hsu et al. } \\
\text { (2016) }\end{array}$ & $\begin{array}{l}\text { Changhua County, Taiwan } \\
\text { (residential area) }\end{array}$ & $52.4 \pm 27.2$ & $\begin{array}{l}\text { Soil dust and crustal metals (44.2\%), coal combustion (24.8\%), oil combustion (23.1\%), traffic-related emission } \\
(7.9 \%)\end{array}$ \\
\hline $\begin{array}{l}\text { Manousakas } \\
\text { et al. (2015) }\end{array}$ & Megalopolis, Greece (urban) & 24.3 & $\begin{array}{c}\text { Soil dust (33\%), biomass burning (19\%), road dust (15\%), power plant emissions (13\%), traffic (12\%), sea spray } \\
(8 \%)\end{array}$ \\
\hline $\begin{array}{l}\text { Waked et al. } \\
\qquad(2014)\end{array}$ & $\begin{array}{l}\text { Lens, France (urban } \\
\text { background) }\end{array}$ & $21 \pm 13$ & $\begin{array}{l}\text { Aged marine aerosol (19\%), nitrate-rich (14\%), sulfate-rich (14\%), biomass burning (13\%), dust (13\%), } \\
\text { primary biogenic (9\%), sea salt (8\%), traffic exhaust (6\%), oil combustion (4\%) }\end{array}$ \\
\hline $\begin{array}{l}\text { Gugamsetty } \\
\text { et al. (2012) }\end{array}$ & $\begin{array}{l}\text { Shinjung station, New Taipei } \\
\text { City, Taiwan (urban) }\end{array}$ & $\begin{array}{l}39.45 \\
\pm 11.58\end{array}$ & Soil dust (34\%), vehicle exhaust (25\%), secondary aerosol (24.3\%), sea salt (8.4\%), industrial ( $8.3 \%)$ \\
\hline $\begin{array}{l}\text { Alleman et al. } \\
\qquad(2010)\end{array}$ & Dunkirk, France (industrial) & $\begin{array}{l}\text { Ranging from } \\
14 \text { to } 36\end{array}$ & $\begin{array}{l}\text { Road transport (15\%), dust resuspension (13\%), metallurgical coke plant (12.6\%), marine aerosol (12\%), } \\
\text { crustal dust (11\%), petrochemical activities (9.2\%), metallurgical sintering plant (9\%), ferromanganese plant } \\
(6.6 \%)\end{array}$ \\
\hline
\end{tabular}

characterized by high levels of crustal-related elements ( $\mathrm{Si}, \mathrm{Mg}, \mathrm{Al}, \mathrm{Fe}$ ), $\mathrm{Na}, \mathrm{S}, \mathrm{NO}_{3}^{-}, \mathrm{OC}$ and $\mathrm{EC}$, and the absence of $\mathrm{Cl}^{-}$and $\mathrm{NH}_{4}^{+}$. The depletion in $\mathrm{Cl}^{-}$and $\mathrm{NH}_{4}^{+}$levels is caused by the reaction of both $\mathrm{SO}_{2}$ and sulfuric acid $\left(\mathrm{H}_{2} \mathrm{SO}_{4}\right)$ with sea salt particles (Hsu et al., 2007; Song and Carmichael, 1999). Moreover, due to $\mathrm{Mg}^{2+}$ and $\mathrm{Na}^{+}$are considered as tracers of sea salt, the $\mathrm{Mg}^{2+} / \mathrm{Na}^{+}$mass ratio was evaluated taking into account days with an aged sea salt contribution higher than $50 \%$ of $\mathrm{PM}_{10}$, obtaining a mean value of $0.22 \pm 0.06$. Beuck et al. (2011) and Yao et al. (2003) reported for aged sea salt aerosols, a ratio close to 0.12 , which agrees with the theoretical value reported by Seinfeld and Pandis (2016). The difference observed between our results and these studies may be due to the contribution of mineral particles to this factor. Accordingly, we have decided to identify this factor as "Aged sea salt" following the criteria found in other papers (Song and Carmichael, 1999; Yubero et al., 2011).

\subsubsection{Secondary aerosols source}

The third factor is dominated by the presence of $\mathrm{S}, \mathrm{NO}_{3}^{-}$and $\mathrm{NH}_{4}^{+}$, which represent the formation of secondary inorganic aerosols (Salvador et al., 2004). This is the predominant source of aerosol in suburban stations studied by Amato et al. (2016) and Waked et al. (2014), with contributions to $\mathrm{PM}_{10}$ from 28 to $40 \%$ and where the traffic contribution does not exceed $20 \%$ (Table 2). Secondary aerosols are formed from chemical and photochemical processes that occur between pollutants, generally released to the atmosphere by anthropogenic sources (Gugamsetty et al., 2012). The contribution from this source to $\mathrm{PM}_{10}$ in León was similar in the four seasons (Fig. 3). During summer and spring, the formation of secondary sulfates is promoted by the solar radiation, while in winter and autumn, the secondary nitrates are more important (Querol et al., 2004).

\subsubsection{Dust source}

This factor is dominated by crustal elements as $\mathrm{Si}, \mathrm{Al}, \mathrm{Ti}, \mathrm{Fe}, \mathrm{Ca}, \mathrm{K}$ and $\mathrm{Mg}$. The arrival of dust from Saharan outbreaks and soil resuspension are the main sources contributing to this factor. Besides, the cement factory located in La Robla, at approximately $30 \mathrm{~km}$ north of the sampling site, is probably another important source of mineral particles, due to it works mainly with clinker, which is a material consisting of $\mathrm{CaO}, \mathrm{SiO}_{2}$, $\mathrm{Al}_{2} \mathrm{O}_{3}, \mathrm{Fe}_{2} \mathrm{O}_{3}$, among others. Regarding the annual contribution to $\mathrm{PM}_{10}$ mass concentration, this factor represents $13 \%$ (Fig. 3), with seasonal percentages ranging between $8 \%$ (in spring) and 23\% (in summer). Amato et al. (2016) reported values ranging between 1 and $14 \%$ of $\mathrm{PM}_{10}$ in other cities also affected by Saharan dust intrusions, while Manousakas et al. (2015) observed a contribution of 33\% of soil dust in Megalopolis, Greece (Table 2). Moreover, Gugamsetty et al. (2012) and Hsu et al. (2016) observed contributions of 44 and 34\% from soil dust to $\mathrm{PM}_{10}$, due to local activities.

\subsubsection{Marine source}

Due to the significant loading of $\mathrm{Cl}, \mathrm{Na}$ and $\mathrm{Mg}$, the fifth factor is defined as marine (Borbély-Kiss et al., 1999; Salvador et al., 2004). The highest contribution from this factor was obtained in winter, followed by spring ( $14 \%$ and $7 \%$, respectively). Although León is not in the coastal region, the marine contribution seems important in winter, when the highest $\mathrm{Na}$ and $\mathrm{Cl}$ concentrations were registered $\left(0.26 \pm 0.23 \mu \mathrm{g} \mathrm{m}^{-3}\right.$ and $0.46 \pm 0.37 \mu \mathrm{g} \mathrm{m}^{-3}$, respectively). It can be attributed to the Atlantic frontal system, that is more frequent in winter and spring, and which generally reaches the city of León when penetrating from the Atlantic Ocean, approximately $200 \mathrm{~km}$ far from the city.

\subsubsection{Biomass burning source}

This factor is characterized by high amounts of levoglucosan. Constituents such as $\mathrm{K} \mathrm{NO}_{3}^{-}$and $\mathrm{OC}$, which are also related to biomass burning (Sharma et al., 2016), were also present in small proportions. The highest contribution of this factor was obtained in winter and autumn (Fig. 3), when the emissions from residential heating devices are more frequent and intense. Moreover, in summer and spring, a small contribution of biomass burning emissions to the aerosol loads, could be attributed to wildfire events, which are more often in the northwest of the Peninsula in the warmer months (Alonso-Blanco et al., 2012, 2018).

\subsubsection{Unknown sources}

The unknown factor represents approximately $6 \%$ of the $\mathrm{PM}_{10}$ mass concentration. This last source could represent a sum of small sources of atmospheric aerosol, among which some pharmaceutical industries, coal combustion emissions and/or primary biogenic emissions. Waked et al. (2014) reported in Lens, France, an annual contribution of primary biogenic emissions to $\mathrm{PM}_{10}$ of $9 \%$ (Table 2), which reaches up to $20 \%$ in summer, due to an increase in the concentration of fungal spores, fern spores, pollen grains and fragments of plants in the air, in addition to 
the presence of large agricultural activities near the sampling site. The increase in the contribution of this unknown source, especially during the summer (9\%), is probably due to a large contribution of primary biogenic emissions during the warmer months. Fernández-González et al. (1993) showed that the pollen season in León mainly occurs between late spring and summer. Therefore, in these months, aerosol concentrations may be affected by primary biogenic emissions due to high levels of pollen spores in the atmosphere.

\subsubsection{Location of the sources}

Fig. 4 depicts the daily source contributions of particulate matter as a function of wind speed and direction in León city for each source. Polar plots show, in general, an increase in the concentration with wind speed. Yu et al. (2004) and Carslaw et al. (2006) described that pollutants emitted from sources far from the sampling site or at higher altitudes, need high wind speeds to be transported to the monitoring site.

The main source contributing to traffic and biomass burning factors is in the first quadrant, where the ring road and the neighboring towns are located (Fig. 1). Biomass burning emissions are mainly due to the use of domestic heating devices, while traffic source is dominated by exhaust emissions from road traffic, but there may be some overlap in emissions from heating appliances. The aged sea salt polar plot shows higher concentrations with increasing distance to the receptor, suggesting long-range transport (Carslaw et al., 2006). The Saharan dust and/or the sea salt aerosols that are transported to León city, can undergo oxidative processes by reacting with anthropogenic emissions produced in the city center. Thus, the highest concentration for the aged sea salt factor is located to the third quadrant. The polar plot for the dust source shows a decrease in concentration with increasing wind speed, suggesting sources with greatest impact in stagnant atmospheric conditions.
3.3. Relationship between source contributions and circulation weather types

During the sampling period, the more frequent weather types were pure cyclonic $(\mathrm{C})$, with $13 \%$ of the days, followed by pure anticyclonic (A) and NE both with $12 \%$ of the sampling days (Figs. 5a and S1).

The highest $\mathrm{PM}_{10}$ mean values were observed for the hybrid cyclonic types with $\mathrm{S}$ and $\mathrm{E}$ components, CS $\left(33 \mu \mathrm{g} \mathrm{m}^{-3}\right), \mathrm{CE}\left(32 \mu \mathrm{g} \mathrm{m}^{-3}\right)$, CSE $\left(28 \mu \mathrm{g} \mathrm{m}^{-3}\right)$ and $\mathrm{S}\left(27 \mu \mathrm{g} \mathrm{m}^{-3}\right)$. Furthermore, Fig. S2 indicates that the directional CWTs, with wind directions from the first and fourth quadrant showed the highest $\mathrm{PM}_{10}$ mean values with low wind speed $\left(<2 \mathrm{~m} \mathrm{~s}^{-1}\right)$. Traffic and secondary aerosol factors have a major contribution during CE, CSE, CS and S weather types, due to the increased emissions from heating devices and from road traffic (Fig. 5b), especially during cold months. Moreover, the lowest $\mathrm{PM}_{10}$ mean values are associated with CNW $\left(13 \mu \mathrm{g} \mathrm{m}^{-3}\right)$, AS $\left(15 \mu \mathrm{g} \mathrm{m}^{-3}\right)$, AW $\left(16 \mu \mathrm{g} \mathrm{m}^{-3}\right)$ and $\mathrm{AE}\left(17 \mu \mathrm{g} \mathrm{m}^{-3}\right)$ (Fig. 5a and Table S3) encompassing higher contributions from traffic and aged sea salt. Nevertheless, these CWTs lasted only 1 day, in the case of AS, 3 days for AE and 4 days for CNW and AW.

Anticyclonic types, A and AN, exhibited high contribution of aged sea salt (37\% and 35\%, respectively), secondary (14 and $15 \%$, respectively) and dust (15 and 16\%, respectively) factors (Fig. $5 \mathrm{~b}$ ). These weather types are more frequent in summer, when the high pressure system of the Azores during the days with northerly weather types favor a high photochemical activity (Santurtún et al., 2015). Fernández-Raga et al. (2017) reported that the atmospheric stability conditions of the anticyclonic type causes a greater local dust resuspension and an inhibition of the dispersion. In addition, the Saharan dust intrusions are frequently related to anticyclonic situations (Díaz et al., 2017). Besides, N and NW weather types showed a high contribution from aged sea salt (30
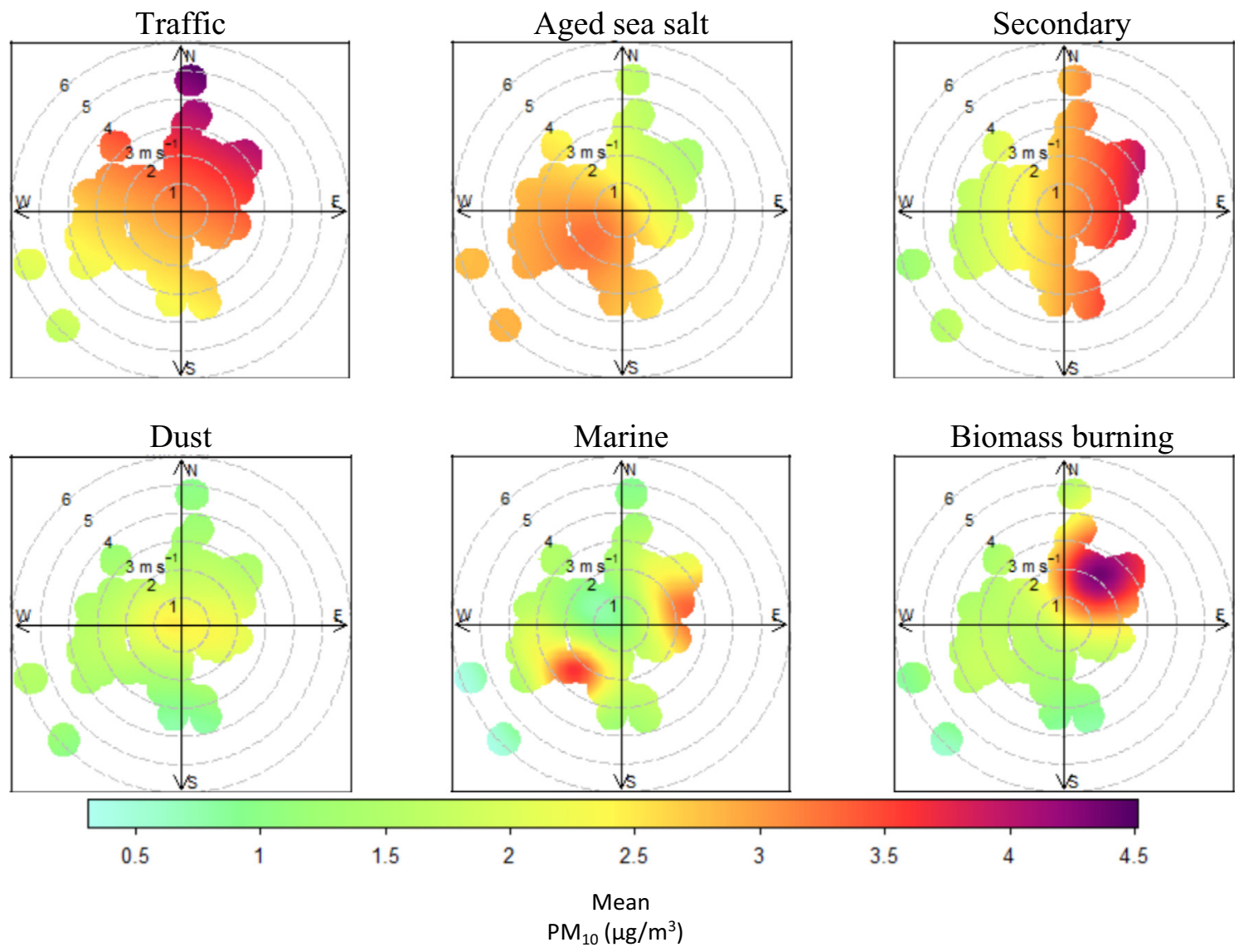

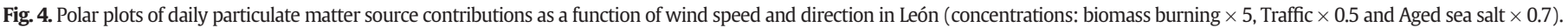


a)

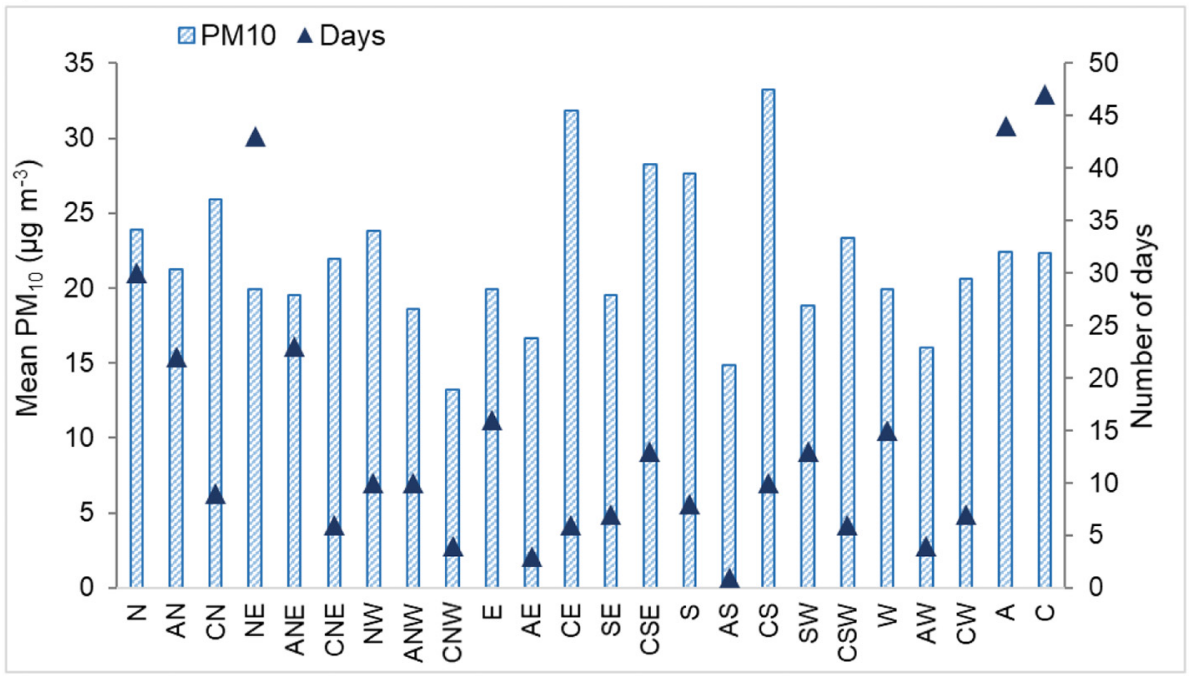

b)

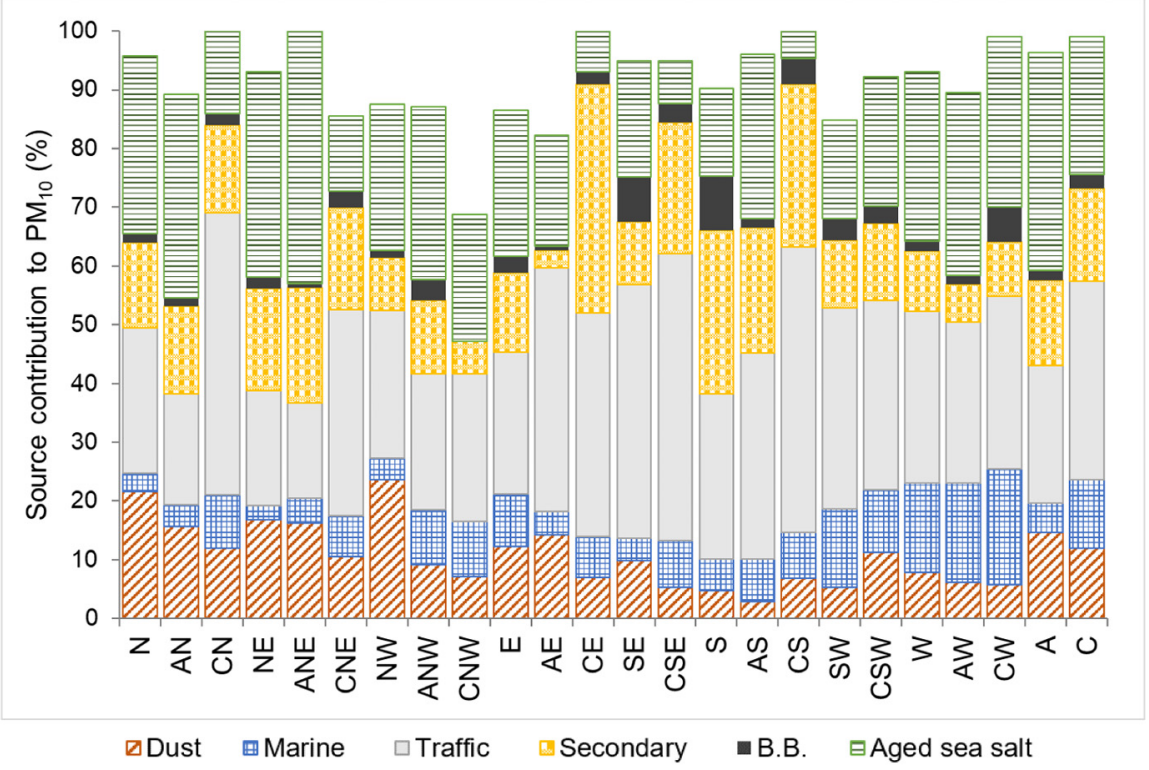

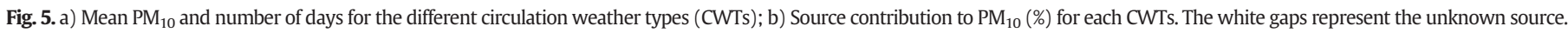

and $25 \%$, respectively) and dust (22 and $24 \%$, respectively) factors (Fig. 5b).

The marine source registered the highest $\mathrm{PM}_{10}$ percentages for cyclonic types CW, AW and W with 20\%, 17\% and 15\%, respectively (Fig. 5b). Westerly weather types are characterized by the presence of humid air masses loaded with marine salts from the Atlantic Ocean. In León, westerly weather types are more frequent in winter and spring (with a frequency of $19 \%$ and $21 \%$ of the winter and spring days, respectively) than in summer and autumn ( $2 \%$ and $8 \%$ of days, respectively). Due to their instability, these CWTs are associated with significant rainfall events (Fernández-Raga et al., 2017; Santos et al., 2005). Moreover, the main $\mathrm{PM}_{10}$ contribution from biomass burning was recorded for the directional S type, with $9 \%$ and $\mathrm{SE}$, with $8 \%$ of the $\mathrm{PM}_{10}$ contribution. These CWTs are more frequent in spring and autumn concurring with the use of domestic heating devices.

\subsection{Aerosol composition and geostrophic flow}

In order to determinate the association between each aerosol source contribution and the geostrophic flow, an automatic linear modelling (IBM SPSS Statistics 24) by stepwise, was used. For the construction of the linear models, all the elements analyzed in the PMF model, the $\mathrm{PM}_{10}$ source contribution from PMF and the geostrophic flow were introduced in the models. The dependent and independent variables as well as the coefficients of the models that are statistically significant $(p<0.05)$ are shown in Table 3 . Since $\mathrm{R}^{2}$ measures the explanatory capacity of the variable $X$ over the variable $Y$, the improvement of $R^{2}$ with the inclusion of each variable can be seen in Table S4.

The linear models showed a clear dependence on the main tracer elements for each factor. Regarding the geostrophic flow, a positive coefficient for westerly flows (WF) in marine factor concentrations was observed. This result is in line with the fact that the western air masses are responsible for transporting large amounts of sea salts from the Atlantic Ocean to León. Moreover, secondary and traffic factors had positive coefficients for southerly flows (SF). This may be due to the significant contribution of anthropogenic emissions from the city center, which include traffic, heating devices and pharmaceutical industries (located at about $8 \mathrm{~km}$ south of the sampling site) added to the anthropogenic emissions of other cities located further south.

The southerly shear vorticity (ZS) appears with a significant coefficient only in aged sea salt and dust factors. In the case of aged sea salt, the negative $\mathrm{ZS}$ coefficient confirms that this factor is mainly favored by 
Table 3

Intercept $(\beta)$, (coefficients $\pm \sigma$ ) and the adjusted $\mathrm{R}^{2}$ of multi-linear regression models of $\mathrm{PM}_{10}$ for each source contribution. Each summand in the equations are expressed in $\mu \mathrm{g} \mathrm{m}^{-3}$.

\begin{tabular}{|c|c|c|c|}
\hline \multirow[t]{2}{*}{$\mathrm{PM}_{10}$ Source } & \multicolumn{2}{|r|}{ Multi-linear regression models } & \multirow{2}{*}{$\begin{array}{l}\text { Adjusted } \\
\mathrm{R}^{2}\end{array}$} \\
\hline & $\beta$ & (Coefficients $\pm \sigma$ ) & \\
\hline Traffic & $-2.6 \pm 0.3$ & {$[\mathrm{EC}](10.1 \pm 0.4)+[\mathrm{Se}](368 \pm 96)+(\mathrm{SF})\left(1.0 \times 10^{-3} \pm 0.2 \times 10^{-3}\right)+[\mathrm{Cu}](352 \pm 74)$} & 0.91 \\
\hline Aged sea salt & $2.2 \pm 0.2$ & $\begin{array}{l}{\left[\mathrm{SO}_{4}^{2-}\right](3.2 \pm 0.2)-\left[\mathrm{NH}_{4}^{+}\right](4.2 \pm 0.4)+[\mathrm{Na}](21.0 \pm 1.2)-[\mathrm{Cl}](11.8 \pm 0.8)+\left[\mathrm{NO}_{3}^{-}\right](0.6 \pm 0.2)-(\mathrm{ZS})\left(3.13 \times 10^{-4}\right.} \\
\left. \pm 1.5 \times 10^{-4}\right)\end{array}$ & 0.81 \\
\hline Secondary & $-0.32 \pm 0.09$ & {$\left[\mathrm{NH}_{4}^{+}\right](8.16 \pm 0.19)-\left[\mathrm{NO}_{3}^{-}\right](0.74 \pm 0.08)+\left[\mathrm{SO}_{4}^{2-}\right](0.35 \pm 0.08)+(\mathrm{SF})\left(1.95 \times 10^{-4} \pm 0.88 \times 10^{-4}\right)$} & 0.97 \\
\hline Dust & $-0.70 \pm 0.06$ & $\begin{array}{l}{[\mathrm{Al}](10.35 \pm 0.41)+[\mathrm{Ca}](3.41 \pm 0.39)-(\mathrm{SF})\left(3.36 \times 10^{-4} \pm 0.56 \times 10^{-4}\right)+(\mathrm{ZS})\left(2.39 \times 10^{-4} \pm 0.51 \times 10^{-4}\right)+[\mathrm{Si}]} \\
(0.46 \pm 0.19)\end{array}$ & 0.98 \\
\hline Marine & $-0.44 \pm 0.03$ & {$[\mathrm{Cl}](5.53 \pm 0.13)+[\mathrm{Na}](3.32 \pm 0.21)+(\mathrm{WF})\left(8.22 \times 10^{-5} \pm 3.20 \times 10^{-5}\right)$} & 0.98 \\
\hline $\begin{array}{l}\text { Biomass } \\
\text { burning }\end{array}$ & $\begin{array}{l}-0.077 \\
\pm 0.012\end{array}$ & [Levoglucosan] (58.740 \pm 0.441$)$ & 0.99 \\
\hline
\end{tabular}

anticyclonic situations, as discussed in Section 3.3. The SF negative and ZS positive coefficients obtained for the dust factor deserve attention, suggesting that this input is favored by cyclonic and northern conditions. However, Saharan dust intrusions, which can be considered as the main dust source, are mainly associated with anticyclonic situations and southern flows in the Iberian Peninsula (Díaz et al., 2017; Oduber et al., 2019; Titos et al., 2017). These results, along with those observed for the CWTs, for which the highest $\mathrm{PM}_{10}$ contribution from the dust factor is associated with northerly types, confirm that the cement factory in La Robla could be an important source of dust that must be taken into account.

Finally, the biomass burning factor shows no relation with geostrophic flow, probably because it is a more local source. The source contribution to $\mathrm{PM}_{10}$ (\%) for each CWTs grouped into anticyclonic, cyclonic and directional types (Fig. S3) supports the previous results.

Assuming that the six factors described in Table 3 are the only sources of $\mathrm{PM}_{10}$ in León, and applying each linear regression model to calculate the individual contribution of each source, it is possible to calculate the daily mass concentration of $\mathrm{PM}_{10}$ from these six sources. For PMF, the $\mathrm{PM}_{10}$ from each source is predicted by the model software. For MLR, the $\mathrm{PM}_{10}$ from each source is determined by the equations shown in Table 3. Finally, the $\mathrm{PM}_{10}$ predicted by both models is determined by this expression:

$$
\begin{aligned}
P M_{10}\left(\mu \mathrm{g} \mathrm{m} \mathrm{m}^{-3}\right)= & P M_{10_{\text {Truffic }}}+P M_{10_{\text {Aged sea salt }}}+P M_{10_{\text {Seconday }}}+P M_{10_{\text {Dust }}} \\
& +P M_{10_{\text {Marine }}}+P M_{10_{\text {Biomassurning }}}
\end{aligned}
$$

The percentage of the total $\mathrm{PM}_{10}$ captured by the MLR parameterization is, on average, $90.6 \%$. This allows comparing the results obtained by the PMF model and those derived from the linear models presented in this work. The linear fit of Fig. $6 \mathrm{a}$ and $\mathrm{b}$ shows $\mathrm{a} \mathrm{R}^{2}$ of 0.64 and 0.67 , respectively (Fig. S4), which indicates that the results obtained through the application of the linear models are similar to those obtained by $\mathrm{PMF}$ for the $\mathrm{PM}_{10}$ daily reconstruction.

The Kruskal-Wallis $\mathrm{H}$ test shows that there are no significant differences between the $\mathrm{PM}_{10}$ concentrations obtained by PMF and those estimated by the multi-linear model. Furthermore, the relationship is close to 1:1 (Fig. 6c). In fact, the linear model has been built from PMF results. That means that both models can be used interchangeably, retaining the quality of the prediction. The main advantage for linear model is that there is no need to know the concentration of all the chemical compounds used in PMF (neither having a long temporal series). Furthermore, if only a source is required, the number of variables needed is considerably smaller than for PMF (Table 3). Additionally, the use of linear model offers the possibility to consider new variables related to the atmospheric conditions namely the geostrophic flow readily found on the internet.

\section{Conclusions}

A $\mathrm{PM}_{10}$ sampling campaign was carried out in a suburban area of León city, Spain, between March 2016 and March 2017, with the aim of determining aerosol sources and their association with air masses and circulation weather types. The positive matrix factorization (PMF) analysis allowed to identify 6 main aerosol sources: traffic, aged sea salt, secondary aerosols, dust, marine and biomass burning, with an annual contribution to $\mathrm{PM}_{10}$ of $29 \%, 26 \%, 16 \%, 13 \%, 14 \%$ and $3 \%$, respectively. Traffic and secondary aerosols factors showed the highest $\mathrm{PM}_{10}$ contribution for the hybrid cyclonic weather types CS and CSE. Anticyclonic types A, AN and ANE, exhibited high values of secondary aerosols (between 14 and 19\%), aged sea salt (35-44\%) and dust (15-16\%) factors. Besides, the dust factor showed the highest contributions for northerly types, N (22\%) and NW (24\%).

Based on both the PMF results and the parameters of weather types associated with the geostrophic flow (SF, WF, ZS and ZW), it was possible to construct multi-linear regression models for each aerosol source. This allowed to describe locally the relationship of the circulation weather types and the emissions from each source to the daily concentration of $\mathrm{PM}_{10}$. The results showed that the contribution of each factor to $\mathrm{PM}_{10}$ depends on the main tracer elements of each source and on the geostrophic flow.

The daily mass concentration of $\mathrm{PM}_{10}$, estimated from the multilinear models, agreed with the results obtained by the PMF model, leading to a coefficient of determination of 0.94 . Unlike the PMF method, these linear models can be applied to determine the contribution of $\mathrm{PM}_{10}$ sources in León only by knowing the geostrophic flow (with data readily found on the internet) and the concentration of the elements involved in the model.

The results show that the combination of PMF models and circulation weather types can be a useful dual tool in the local analysis of source apportionment. The application of these results in local air quality models can provide helpful information for formulating mitigation measures.

\section{CRediT authorship contribution statement}

Fernanda Oduber: Conceptualization, Methodology, Formal analysis, Investigation, Writing - original draft, Visualization. Ana Isabel Calvo: Conceptualization, Methodology, Resources, Writing - original draft, Visualization, Supervision, Project administration. Amaya Castro: Conceptualization, Methodology, Resources, Writing - review \& editing, Supervision, Project administration. Carlos Blanco-Alegre: Investigation, Visualization, Writing - review \& editing. Célia Alves: Investigation, Writing - original draft, Supervision, Funding acquisition. Giulia Calzolai: Investigation, Writing - review \& editing. Silvia Nava: Investigation, Writing - review \& editing. Franco Lucarelli: Investigation, Writing - review \& editing. Teresa Nunes: Investigation, Writing - review \& editing. Joana Barata: Investigation, Writing - review \& editing. Roberto Fraile: Conceptualization, Methodology, Resources, Writing original draft, Visualization, Supervision, Project administration, Funding acquisition.

\section{Declaration of competing interest}

The authors declare that they have no known competing financial interests or personal relationships that could have appeared to influence the work reported in this paper. 
a)

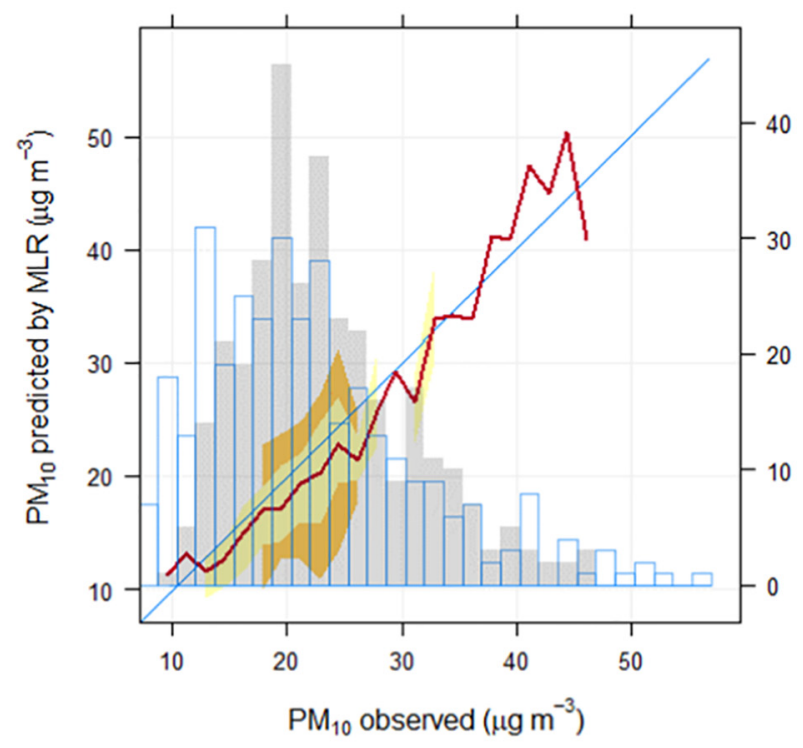

25/75th percentile 10/90th percentile

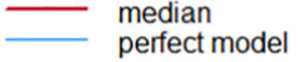

b)

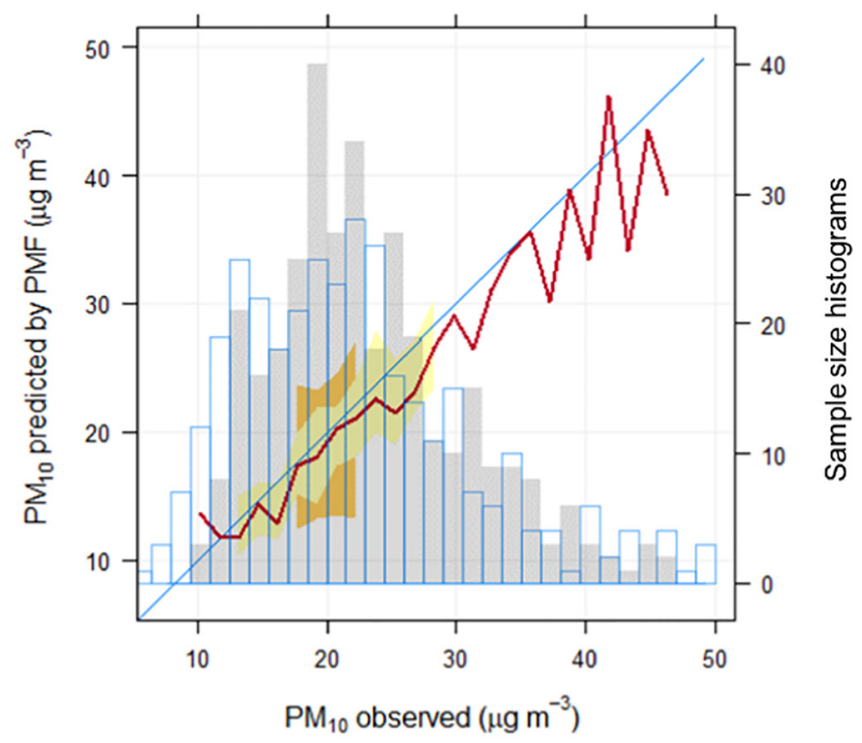

$\begin{array}{lll}25 / 75 \text { th percentile } & \quad \begin{array}{l}\text { median } \\ \text { perfect model }\end{array}\end{array}$

c)

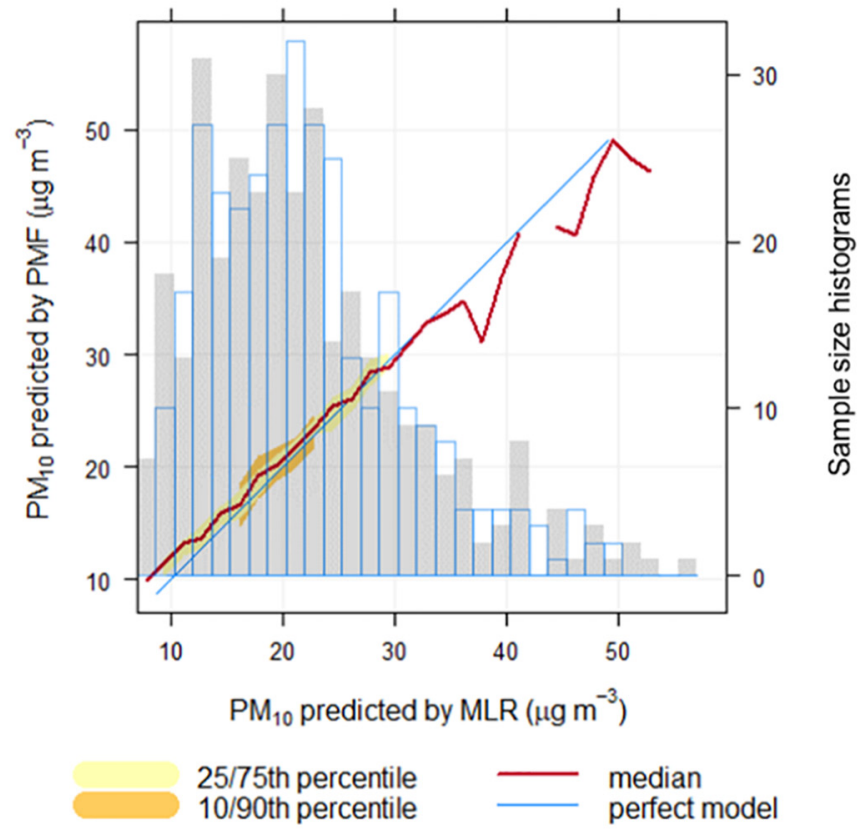

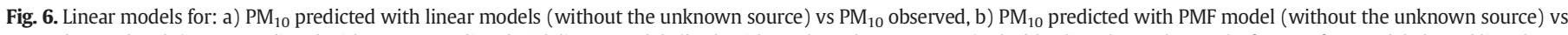

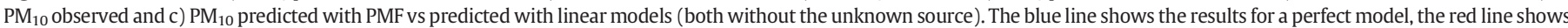

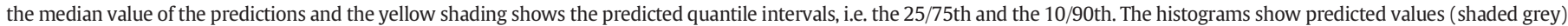
and observed values (shown as a blue line). (For interpretation of the references to colour in this figure legend, the reader is referred to the web version of this article.)

\section{Acknowledgments}

This study was partially supported by the Spanish Ministry of Economy and Competitiveness (Grant TEC2014-57821-R), the University of León (Programa Propio 2015/00054/001 and 2018/00203/001) and the AERORAIN project (Ministry of Economy and Competitiveness, Grant CGL2014-52556-R, co-financed with European FEDER funds). F.
Oduber acknowledges the grant BES-2015-074473 from the Spanish Ministry of Economy and Competitiveness. C. Blanco-Alegre acknowledges the grant FPU16-05764 from the Spanish Ministry of Education, Culture and Sport. Thanks are also due for the financial support to CESAM (UIDB/50017/2020+UIDP/50017/2020), to FCT/MCTES through national funds, and the co-funding by the FEDER, within the PT2020 Partnership Agreement and Compete 2020. 


\section{Appendix A. Supplementary data}

Supplementary data to this article can be found online at https://doi. org/10.1016/j.scitotenv.2020.142045.

\section{References}

Agostinelli, C., 2002. Robust stepwise regression. J. Appl. Stat. 29, 825-840. https://doi. org/10.1080/02664760220136168.

Aldabe, J., Elustondo, D., Santamaría, C., Lasheras, E., Pandolfi, M., Alastuey, A., Querol, X Santamaría, J.M., 2011. Chemical characterisation and source apportionment of PM2.5 and PM10 at rural, urban and traffic sites in Navarra (North of Spain). Atmos. Res. 102, 191-205. https://doi.org/10.1016/j.atmosres.2011.07.003.

Alleman, L.Y., Lamaison, L., Perdrix, E., Robache, A., Galloo, J., 2010. PM10 metal concentrations and source identification using positive matrix factorization and wind sectoring in a French industrial zone. Atmos. Res. 96, 612-625. https://doi.org/10.1016/j. atmosres.2010.02.008.

Alonso-Blanco, E., Calvo, A.I., Fraile, R., Castro, A., 2012. The influence of wildfires on aerosol size distributions in rural areas. Sci. World J. 2012, 1-13. https://doi.org/10.1100/ 2012/735697.

Alonso-Blanco, E., Castro, A., Calvo, A.I., Pont, V., Mallet, M., Fraile, R., 2018. Wildfire smoke plumes transport under a subsidence inversion: climate and health implications in a distant urban area. Sci. Total Environ. 619-620, 988-1002. https://doi.org/10.1016/j. scitotenv.2017.11.142.

Alves, C.A., Lopes, D.J., Calvo, A.I., Evtyugina, M., Rocha, S., Nunes, T., 2015. Emissions from light-duty diesel and gasoline in-use vehicles measured on chassis dynamometer test cycles. Aerosol Air Qual. Res. 15, 99-116. https://doi.org/10.4209/aaqr.2014.01.0006.

Amato, F., Alastuey, A., Karanasiou, A., Lucarelli, F., Nava, S., Calzolai, G., Severi, M., Becagli, S., Gianelle, V.L., Colombi, C., Alves, C., Custódio, D., Nunes, T., Cerqueira, M., Pio, C., Eleftheriadis, K., Diapouli, E., Reche, C., Minguillón, M.C., Manousakas, M., Maggos, T., Vratolis, S., Harrison, R.M., Querol, X., 2016. AIRUSE-LIFE+: a harmonized PM speciation and source apportionment in five southern European cities. Atmos. Chem. Phys. 16, 3289-3309. https://doi.org/10.5194/acp-16-3289-2016.

Art́iñano, B., Salvador, P., Alonso, D.G., Querol, X., Alastuey, A., 2003. Anthropogenic and natural influence on the PM10 and PM2.5 aerosol in Madrid (Spain). Analysis of high concentration episodes. Environ. Pollut. 125, 453-465. https://doi.org/10.1016/ S0269-7491(03)00078-2.

Baltaci, H., Akkoyunlu, B.O., Arslan, H., Yetemen, O., Ozdemir, E.T., 2019. The influence of meteorological conditions and atmospheric circulation types on PM10 levels in western Turkey. Environ. Monit. Assess. 191, 606-619. https://doi.org/10.1007/s10661019-7609-7.

Beuck, H., Quass, U., Klemm, O., Kuhlbusch, T.A.J., 2011. Assessment of sea salt and mineral dust contributions to PM10 in NW Germany using tracer models and positive matrix factorization. Atmos. Environ. 45, 5813-5821. https://doi.org/10.1016/j. atmosenv.2011.07.010.

Blanco-Alegre, C., Calvo, A.I., Coz, E., Castro, A., Oduber, F., Prévôt, A.S.H., Močnik, G., Fraile R., 2019. Quantification of source specific black carbon scavenging using an aethalometer and a disdrometer. Environ. Pollut. 246, 336-345. https://doi.org/ 10.1016/j.envpol.2018.11.102.

Borbély-Kiss, I., Koltay, E., Szabó, G.Y., Bozó, L., Tar, K., 1999. Composition and sources of urban and rural atmospheric aerosol in eastern Hungary. J. Aerosol Sci. 30, 369-391. https://doi.org/10.1016/S0021-8502(98)00051-2.

Calvo, A.I., Pont, V., Olmo, F.J., Castro, A., Alados-Arboledas, L., Vicente, A.M., FernándezRaga, M., Fraile, R., 2012. Air masses and weather types: a useful tool for characterizing precipitation chemistry and wet deposition. Aerosol Air Qual. Res. 12, 856-878. https://doi.org/10.4209/aaqr.2012.03.0068.

Calvo, A.I., Alves, C., Castro, A., Pont, V., Vicente, A.M., Fraile, R., 2013. Research on aerosol sources and chemical composition: past, current and emerging issues. Atmos. Res. 120-121, 1-28. https://doi.org/10.1016/j.atmosres.2012.09.021.

Carslaw, D.C., 2015. The Openair Manual-Open-Source Tools for Analysing Air Pollution Data.

Carslaw, D.C., Ropkins, K., 2012. Openair - an r package for air quality data analysis. Environ. Model. Softw. 27-28, 52-61. https://doi.org/10.1016/j.envsoft.2011.09.008,

Carslaw, D.C., Beevers, S.D., Ropkins, K., Bell, M.C., 2006. Detecting and quantifying aircraft and other on-airport contributions to ambient nitrogen oxides in the vicinity of a large international airport. Atmos. Environ. 40, 5424-5434. https://doi.org/10.1016 j.atmosenv.2006.04.062.

Castro, A., Alonso-Blanco, E., González-Colino, M., Calvo, A.I., Fernández-Raga, M., Fraile, R., 2010. Aerosol size distribution in precipitation events in León, Spain. Atmos. Res. 96, 421-435. https://doi.org/10.1016/j.atmosres.2010.01.014.

Cesari, D., Donateo, A., Conte, M., Merico, E., Giangreco, A., Giangreco, F., Contini, D., 2016. An inter-comparison of PM2.5 at urban and urban background sites: chemical characterization and source apportionment. Atmos. Res. 174-175, 106-119. https://doi. org/10.1016/j.atmosres.2016.02.004.

Cusack, M., Pérez, N., Pey, J., Alastuey, A., Querol, X., 2013. Source apportionment of fine $\mathrm{PM}$ and sub-micron particle number concentrations at a regional background site in the western Mediterranean: a 2.5 year study. Atmos. Chem. Phys. 13, 5173-5187. https://doi.org/10.5194/acp-13-5173-2013.

Díaz, J., Linares, C., Carmona, R., Russo, A., Ortiz, C., Salvador, P., Trigo, R.M., 2017. Saharan dust intrusions in Spain: health impacts and associated synoptic conditions. Environ. Res. 156, 455-467. https://doi.org/10.1016/j.envres.2017.03.047.

Dunn, O.J., 1964. Multiple comparisons using rank sums. Technometrics 6, 241-252. https://doi.org/10.1080/00401706.1964.10490181.
Fernández-González, D., Suarez-Cervera, M., Díaz-González, T., Valencia-Barrera, R.M., 1993. Airborne pollen and spores of León (Spain). Int. J. Biometeorol. 37, 89-95. https://doi.org/10.1007/BF01214387.

Fernández-Raga, M., Castro, A., Marcos, E., Palencia, C., Fraile, R., 2017. Weather types and rainfall microstructure in Leon, Spain. Int. J. Climatol. 37, 1834-1842. https://doi.org/ $10.1002 /$ joc.4816.

Galindo, N., Nicolás, J.F., Yubero, E., Caballero, S., Pastor, C., Crespo, J., 2008. Factors affecting levels of aerosol sulfate and nitrate on the Western Mediterranean coast. Atmos. Res. 88, 305-313. https://doi.org/10.1016/j.atmosres.2007.11.024.

Grego, J.M., 1993. Generalized linear models and process variation. J. Qual. Technol. 25, 288-295. https://doi.org/10.1080/00224065.1993.11979474.

Gugamsetty, B., Wei, H., Liu, C.-N., Awasthi, A., Hsu, S.-C., Tsai, C.-J., Roam, G.-D., Wu, Y.-C., Chen, C.-F., 2012. Source characterization and apportionment of PM10, PM2.5 and PM0.1 by using positive matrix factorization. Aerosol Air Qual. Res. 12, 476-491. https://doi.org/10.4209/aaqr.2012.04.0084.

Gvozdić, V., Kovač-Andrić, E., Brana, J., 2011. Influence of meteorological factors NO2, SO2, $\mathrm{CO}$ and PM10 on the concentration of $\mathrm{O} 3$ in the urban atmosphere of Eastern Croatia. Environ. Model. Assess. 16, 491-501. https://doi.org/10.1007/s10666-011-9256-4.

Hastie, T., Tibshirani, R., Friedman, J., 2009. The Elements of Statistical Learning the Elements of Statistical LearningData Mining, Inference, and Prediction. Second edition. Springer series in statistics https://doi.org/10.1007/978-0-387-84858-7.

Hsu, S., Liu, S.C., Kao, S., Jeng, W., Huang, Y., Tseng, C., Tsai, F., Tu, J., Yang, Y., 2007. Watersoluble species in the marine aerosol from the northern South China Sea: high chloride depletion related to air pollution. J. Geophys. Res. 112, D19304. https://doi.org/ 10.1029/2007JD008844.

Hsu, C.Y., Chiang, H.C., Lin, S.L., Chen, M.J., Lin, T.Y., Chen, Y.C., 2016. Elemental characterization and source apportionment of PM10 and PM2.5 in the western coastal area of central Taiwan. Sci. Total Environ. 541, 1139-1150. https://doi.org/10.1016/j. scitotenv.2015.09.122

Kabe, D.G., 1963. Stepwise multivariate linear regression. J. Am. Stat. Assoc. 58, 770-773. https://doi.org/10.1080/01621459.1963.10500886.

Kanakidou, M., Seinfeld, J.H., Pandis, S.N., Barnes, I., Dentener, F.J., Facchini, M.C., Van Dingenen, R., Ervens, B., Nenes, A., Nielsen, C.J., Swietlicki, E., Putaud, J.P., Balkanski, Y., Fuzzi, S., Horth, J., Moortgat, G.K., Winterhalter, R., Myhre, C.E.L., Tsigaridis, K., Vignati, E., Stephanou, E.G., Wilson, J., 2005. Organic aerosol and global climate modelling: a review. Atmos. Chem. Phys. 5, 1053-1123. https://doi.org/10.5194/ acp-5-1053-2005.

Kruskal, W.H., Wallis, W.A., 1952. Use of ranks in one-criterion variance analysis. J. Am. Stat. Assoc. 47, 583-621. https://doi.org/10.1080/01621459.1952.10483441.

Kuzu, S.L., Saral, A., 2017. The effect of meteorological conditions on aerosol size distribution in Istanbul. Air Qual. Atmos. Heal. 10, 1029-1038. https://doi.org/10.1007/ s11869-017-0491-y.

Kwok, L.K., Lam, Y.F., Tam, C.Y., 2017. Developing a statistical based approach for predicting local air quality in complex terrain area. Atmos. Pollut. Res. https://doi. org/10.1016/j.apr.2016.08.001

Lamb, H.H., 1972. British Isles Weather Types and a Register of Daily Sequence of Circulation Patterns, Geophysical Memoir, HMSO. Her Majesty's stationery office, London.

Lanz, V.A. Alfarra, M.R., Baltensperger, U., Buchmann, B., Hueglin, C., Prévôt, A.S.H., 2007. Source apportionment of submicron organic aerosols at an urban site by factor analytical modelling of aerosol mass spectra. Atmos. Chem. Phys. 7, 1503-1522. https://doi.org/10.5194/acp-7-1503-2007.

Lin, C.-C. Chen, S.-J., Huang K.-L, Hwang W.-I, Chang-Chien, G.-P., Lin, W.-Y, 2005. Characteristics of metals in nano/ultrafine/fine/coarse particles collected beside a heavily trafficked road. Environ. Sci. Technol. 39, 8113-8122. https://doi.org/10.1021/ es048182a.

Liousse, C., Penner, J.E., Chuang, C., Walton, J.J., Eddleman, H., Cachier, H., 1996. A global three-dimensional model study of carbonaceous aerosols. J. Geophys. Res. Atmos. 101, 19411-19432. https://doi.org/10.1029/95JD03426.

Lucarelli, F., Chiari, M., Calzolai, G., Giannoni, M., Nava, S., Udisti, R., Severi, M., Querol, X. Amato, F., Alves, C., Eleftheriadis, K., 2015. The role of PIXE in the AIRUSE project "testing and development of air quality mitigation measures in southern Europe.". Nucl. Instruments Methods Phys. Res. Sect. B Beam Interact. with Mater. Atoms 363, 92-98. https://doi.org/10.1016/j.nimb.2015.08.023.

Manousakas, M., Diapouli, E., Papaefthymiou, H., Migliori, A., Karydas, A.G., PadillaAlvarez, R., Bogovac, M., Kaiser, R.B., Jaksic, M., Bogdanovic-Radovic, I., Eleftheriadis, K. 2015. Source apportionment by PMF on elemental concentrations obtained by PIXE analysis of PM10 samples collected at the vicinity of lignite power plants and mines in megalopolis, Greece. Nucl. Instruments Methods Phys. Res. Sect. B Beam Interact. with Mater. Atoms 349, 114-124. https://doi.org/10.1016/j.nimb.2015.02.037.

Mazzei, F., D’Alessandro, A., Lucarelli, F., Nava, S., Prati, P., Valli, G., Vecchi, R., 2008. Characterization of particulate matter sources in an urban environment. Sci. Total Environ. 401, 81-89. https://doi.org/10.1016/j.scitotenv.2008.03.008.

Mészáros, E., 1999. Fundamentals of Atmospheric Aerosol Chemistry. Acad, Kiado Budapest.

Norris, G., Duvall, R., Brown, S., Bai, S., 2014. EPA Positive Matrix Factorization (PMF) 5.0 Fundamentals and User Guide. U.S. Environmental Protection Agency.

Oduber, F., Castro, A., Calvo, A.I., Blanco-Alegre, C., Alonso-Blanco, E., Belmonte, P., Fraile, R., 2018. Summer-autumn air pollution in León, Spain: changes in aerosol size distribution and expected effects on the respiratory tract. Air Qual. Atmos. Heal. 11, 505-520. https://doi.org/10.1007/s11869-018-0556-6.

Oduber, F., Calvo, A.I., Blanco-Alegre, C., Castro, A., Nunes, T., Alves, C., Sorribas, M., Fernández-González, D., Vega-Maray, A.M., Valencia-Barrera, R.M., Lucarelli, F., Nava, S., Calzolai, G., Alonso-Blanco, E., Fraile, B., Fialho, P., Coz, E., Prevot, A.S.H., Pont, V., Fraile, R., 2019. Unusual winter Saharan dust intrusions at Northwest Spain: air quality, radiative and health impacts. Sci. Total Environ. 669, 213-228. https://doi.org/10.1016/j.scitotenv.2019.02.305. 
Paatero, P., 1997. Least squares formulation of robust non-negative factor analysis. Chemom. Intell. Lab. Syst. 37, 23-35. https://doi.org/10.1016/S0169-7439(96) 00044-5.

Paatero, P., Tapper, U., 1994. Positive matrix factorization: a non-negative factor model with optimal utilization of error estimates of data values. Environmetrics 5 111-126. https://doi.org/10.1002/env.3170050203.

Paatero, P., Eberly, S., Brown, S.G., Norris, G.A., 2014. Methods for estimating uncertainty in factor analytic solutions. Atmos. Meas. Tech 7, 781-797. https://doi.org/10.5194/ amt-7-781-2014

Paraskevopoulou, D., Liakakou, E., Gerasopoulos, E., Mihalopoulos, N., 2015. Sources of atmospheric aerosol from long-term measurements ( 5 years) of chemical composition in Athens, Greece. Sci. Total Environ. 527-528, 165-178. https://doi.org/10.1016/j. scitotenv.2015.04.022.

Pey, J., Querol, X., Alastuey, A., Rodríguez, S., Putaud, J.P., Van Dingenen, R., 2009. Source apportionment of urban fine and ultra-fine particle number concentration in a Western Mediterranean city. Atmos. Environ. 43, 4407-4415. https://doi.org/10.1016/j. atmosenv.2009.05.024.

Pindado, O., Perez, R.M., 2011. Source apportionment of particulate organic compounds in a rural area of Spain by positive matrix factorization. Atmos. Pollut. Res. 2, 492-505. https://doi.org/10.5094/APR.2011.056.

Pio, C., Cerqueira, M., Harrison, R.M., Nunes, T., Mirante, F, Alves, C., Oliveira, C., Sanchez de la Campa, A., Artíñano, B., Matos, M., 2011. OC/EC ratio observations in Europe: re-thinking the approach for apportionment between primary and secondary organic carbon. Atmos. Environ. 45, 6121-6132. https://doi.org/10.1016/j.atmosenv.2011.08.045.

Polissar, A.V., Hopke, P.K., Paatero, P., Malm, W.C., Sisler, J.F., 1998. Atmospheric aerosol over Alaska 2. Elemental composition and sources. J. Geophys. Res. Atmos. 103, 19045-19057. https://doi.org/10.1029/98JD01212.

Querol, X., Alastuey, A., Rodriguez, S., Plana, F., Ruiz, C.R., Cots, N., Massagué, G., Puig, O 2001. PM10 and PM2.5 source apportionment in the Barcelona Metropolitan area, Catalonia, Spain. Atmos. Environ. 35, 6407-6419. https://doi.org/10.1016/S13522310(01)00361-2.

Querol, X., Alastuey, A., Rosa, J. de la, Sánchez-de-la-Campa, A., Plana, F., Ruiz, C.R., 2002. Source apportionment analysis of atmospheric particulates in an industrialised urban site in southwestern Spain. Atmos. Environ. 36, 3113-3125. doi:https://doi. org/10.1016/S1352-2310(02)00257-1.

Querol, X., Alastuey, A., Viana, M.M., Rodriguez, S., Artiñano, B., Salvador, P., Garcia do Santos, S., Fernandez Patier, R., Ruiz, C.R., de la Rosa, J., Sanchez de la Campa, A., Menendez, M., Gil, J.I., 2004. Speciation and origin of PM10 and PM2.5 in Spain. J. Aerosol Sci. 35, 1151-1172. https://doi.org/10.1016/j.jaerosci.2004.04.002.

Ren-Jian, Z., Kin-Fai, H., Zhen-Xing, S., 2012. The role of aerosol in climate change, the environment, and human health. Atmos. Ocean. Sci. Lett. 5, 156-161. https://doi.org/ 10.1080/16742834.2012.11446983.

Russo, A., Trigo, R.M., Martins, H., Mendes, M.T., 2014. $\mathrm{NO}_{2}$, PM10 and $\mathrm{O}_{3}$ urban concentrations and its association with circulation weather types in Portugal. Atmos. Environ. 89, 768-785. https://doi.org/10.1016/j.atmosenv.2014.02.010.

Salvador, P., Artíñano, B., Alonso, D.G., Querol, X., Alastuey, A., 2004. Identification and characterisation of sources of PM10 in Madrid (Spain) by statistical methods. Atmos. Environ. 38, 435-447. https://doi.org/10.1016/j.atmosenv.2003.09.070.

Santos, J.A., Corte-Real, J., Leite, S.M., 2005. Weather regimes and their connection to the winter rainfall in Portugal. Int. J. Climatol. 25, 33-50. https://doi.org/10.1002/ joc.1101.

Santurtún, A., González-Hidalgo, J.C., Sanchez-Lorenzo, A., Zarrabeitia, M.T., 2015. Surface ozone concentration trends and its relationship with weather types in Spain (2001 -2010). Atmos. Environ. 101, 10-22. https://doi.org/10.1016/j.atmosenv.2014.11.005.
Seinfeld, J.H., Pandis, S.N., 2016. Atmospheric Chemistry and Physics: From Air Pollution to Climate Change. 3rd ed. John Wiley \& Sons.

Sharma, S.K., Sharma, A., Saxena, M., Choudhary, N., Masiwal, R., Mandal, T.K., Sharma, C., 2016. Chemical characterization and source apportionment of aerosol at an urban area of Central Delhi, India. Atmos. Pollut. Res. 7, 110-121. https://doi.org/10.1016/ j.apr.2015.08.002.

Simoneit, B.R.T., Schauer, J.J., Nolte, C.G., Oros, D.R., Elias, V.O., Fraser, M.P., Rogge, W.F., Cass, G.R., 1999. Levoglucosan, a tracer for cellulose in biomass burning and atmospheric particles. Atmos. Environ. 33, 173-182.

Song, C.H., Carmichael, G.R., 1999. The aging process of naturally emitted aerosol (sea-salt and mineral aerosol) during long range transport. Atmos. Environ. 33, 2203-2218. https://doi.org/10.1016/S1352-2310(98)00301-X.

Titos, G., Lyamani, H., Pandolfi, M., Alastuey, A., Alados-Arboledas, L., 2014. Identification of fine (PM1) and coarse (PM10-1) sources of particulate matter in an urban environment. Atmos. Environ. 89, 593-602. https://doi.org/10.1016/j.atmosenv.2014.03.001.

Titos, G., Ealo, M., Pandolfi, M., Pérez, N., Sola, Y., Sicard, M., Comerón, A., Querol, X. Alastuey, A., 2017. Spatiotemporal evolution of a severe winter dust event in the western Mediterranean: aerosol optical and physical properties. J. Geophys. Res. Atmos. 122, 4052-4069. https://doi.org/10.1002/2016JD026252.

Trigo, R.M., DaCamara, C.C., 2000. Circulation weather types and their influence on the precipitation regime in Portugal. Int. J. Climatol. 20, 1559-1581. https://doi.org/ 10.1002/1097-0088(20001115)20:13<1559::AID-JOC555>3.0.CO;2-5.

Viana, M., Kuhlbusch, T.A.J., Querol, X., Alastuey, A., Harrison, R.M., Hopke, P.K., Winiwarter W., Vallius, M., Szidat, S., Prévôt, A.S.H., Hueglin, C., Bloemen, H., Wåhlin, P., Vecchi, R., Miranda, A.I., Kasper-Giebl, A., Maenhaut, W., Hitzenberger, R., 2008. Source apportionment of particulate matter in Europe: a review of methods and results. J. Aerosol Sci. 39, 827-849. https://doi.org/10.1016/j.jaerosci.2008.05.007.

Vicente, E.D., Alves, C.A., 2018. An overview of particulate emissions from residential biomass combustion. Atmos. Res. 199, 159-185. https://doi.org/10.1016/j. atmosres.2017.08.027.

Vicente, A., Alves, C., Calvo, A.I., Fernandes, A.P., Nunes, T., Monteiro, C., Almeida, S.M., Pio C., 2013. Emission factors and detailed chemical composition of smoke particles from the 2010 wildfire season. Atmos. Environ. 71, 295-303. https://doi.org/10.1016/j. atmosenv.2013.01.062.

Waked, A., Favez, O., Alleman, L.Y., Piot, C., Petit, J.-E., Delaunay, T., Verlinden, E., Golly, B., Besombes, J.-L., Jaffrezo, J.-L., Leoz-Garziandia, E., 2014. Source apportionment of PM10 in a north-western Europe regional urban background site (Lens, France) using positive matrix factorization and including primary biogenic emissions Atmos. Chem. Phys. 14, 3325-3346. https://doi.org/10.5194/acp-14-3325-2014.

Weissert, L.F., Salmond, J.A., Miskell, G., Alavi-Shoshtari, M., Williams, D.E., 2018. Development of a microscale land use regression model for predicting NO2 concentrations at a heavy trafficked suburban area in Auckland, NZ. Sci. Total Environ. https://doi.org/ 10.1016/j.scitotenv.2017.11.028.

Yao, X., Fang, M., Chan, C.K., 2003. The size dependence of chloride depletion in fine and coarse sea-salt particles. Atmos. Environ. 37, 743-751. https://doi.org/10.1016/ S1352-2310(02)00955-X

Yu, K.N., Cheung, Y.P., Cheung, T., Henry, R.C., 2004. Identifying the impact of large urban airports on local air quality by nonparametric regression. Atmos. Environ. 38, 4501-4507. https://doi.org/10.1016/j.atmosenv.2004.05.034.

Yubero, E., Carratalá, A., Crespo, J., Nicolás, J., Santacatalina, M., Nava, S., Lucarelli, F., Chiari, M., 2011. PM10 source apportionment in the surroundings of the San Vicente de Raspeig cement plant complex in southeastern Spain. Environ. Sci. Pollut. Res. 18, 64-74. https://doi.org/10.1007/s11356-010-0352-9. 